\title{
Sources, fate and distribution of inorganic contaminants in the Svalbard area, representative of a typical Arctic critical environment-a review
}

\author{
Paulina Rudnicka-Kępa (1) • Agata Zaborska
}

Received: 12 January 2021 / Accepted: 12 July 2021 / Published online: 14 October 2021

(C) The Author(s) 2021

\begin{abstract}
Global environmental changes not only contribute to the modification of global pollution transport pathways but can also alter contaminant fate within the Arctic. Recent reports underline the importance of secondary sources of pollution, e.g. melting glaciers, thawing permafrost or increased riverine run-off. This article reviews reports on the European Arctic-we concentrate on the Svalbard region-and environmental contamination by inorganic pollutants (heavy metals and artificial radionuclides), including their transport pathways, their fate in the Arctic environment and the concentrations of individual elements in the ecosystem. This review presents in detail the secondary contaminant sources and tries to identify knowledge gaps, as well as indicate needs for further research. Concentrations of heavy metals and radionuclides in Svalbard have been studied, in various environmental elements since the beginning of the twentieth century. In the last 5 years, the highest concentrations of $\mathrm{Cd}\left(13 \mathrm{mg} \mathrm{kg}^{-1}\right)$ and $\mathrm{As}$ (28 mg kg$)^{-1}$ ) were recorded for organic-rich soils, while levels of $\mathrm{Pb}\left(99 \mathrm{mg} \mathrm{kg}^{-1}\right), \mathrm{Hg}\left(1 \mathrm{mg} \mathrm{kg}^{-1}\right), \mathrm{Zn}$ $\left(496 \mathrm{mg} \mathrm{kg}^{-1}\right)$ and $\mathrm{Cu}\left(688 \mathrm{mg} \mathrm{kg}^{-1}\right)$ were recorded
\end{abstract}

Supplementary information The online version contains supplementary material available at https://doi. org/10.1007/s10661-021-09305-6.

P. Rudnicka-Kępa $(\bowtie) \cdot$ A. Zaborska

Institute of Oceanology Polish Academy of Sciences,

Sopot, Poland

e-mail: prudnicka@iopan.pl for marine sediments. Increased heavy metal concentrations were also recorded in some flora and fauna species. For radionuclides in the last 5 years, the highest concentrations of ${ }^{137} \mathrm{Cs}\left(4500 \mathrm{~Bq} \mathrm{~kg}^{-1}\right)$, ${ }^{238} \mathrm{Pu}\left(2 \mathrm{~Bq} \mathrm{~kg}^{-1}\right)$ and ${ }^{239+}{ }^{240} \mathrm{Pu}\left(43 \mathrm{~Bq} \mathrm{~kg}^{-1}\right)$ were recorded for cryoconites, and the highest concentration of ${ }^{241} \mathrm{Am}\left(570 \mathrm{~Bq} \mathrm{~kg}^{-1}\right)$ was recorded in surface sediments. However, no contamination of flora and fauna with radionuclides was observed.

Keywords Heavy metals · Contaminants · Pollution $\cdot$ Arctic $\cdot$ Polar regions

\section{Introduction}

Despite the low urbanization of the Arctic, an important amount of pollutants gets into this region, from sources that can be even thousands of kilometres away (Macdonald et al., 2005). By the 1960s, contaminants had already been found in the tissues of Arctic marine mammals (Holden \& Marsden, 1967). A breakthrough was a finding of organic contaminants (polychlorinated biphenyls-PCBs) in Canadian Inuit mothers' milk and information about the large amount of radionuclides dumped in the Kara Sea by the former USSR (Macdonald, 2001). In 1991, the Arctic Monitoring and Assessment Program (AMAP) was created, to identify pollution and assess its impact on Arctic ecosystems. The result was the first report published in 1997 (AMAP, 1997), which demonstrated a 
close connection between the Arctic and the rest of the world, caused by the transport of pollutants over long distances. Subsequent research led to further assessment of contamination of the Arctic environment (e.g. AMAP (2002, 2004, 2005, 2006, 2010); Braune et al. (1999); Muir et al. (1999); van Oostdam et al. (1999); Macdonald et al., (2000, 2005, 2010) and, more recently, AMAP $(2011,2016,2019)$ and Fong-McMaster et al. (2020)). A recent report on pollution and its sources, prepared by the Norwegian Polar Institute to identify corrective actions and evaluate current methods, pointed out the widespread problem of long-range pollution in Svalbard and indicated the lack of a system enabling the classification and risk assessment for the Arctic (Granberg et al., 2017).

The first reports confirming secondary pollution of the environment, along with the melting of glaciers, appeared in 2001, when Blais et al. (2001) confirmed the release of persistent chloroorganic compounds from a glacier into Lake Alberta, in Canada. It has also been suggested that, as the climate warms, pollutants previously deposited on glacier surfaces will be released. This phenomenon may be even more important in the future now that a twofold increase in temperature, compared to the global average over the last two decades, has been found in the Arctic (Richter-Menge et al., 2019). During the winter months in 2016 and 2018, it was observed that the surface temperature in the central Arctic was $6{ }^{\circ} \mathrm{C}$ higher than the average from 1981-2010 (Overland et al., 2018), and in the years 2006-2015, there was a loss of glaciers in the Arctic at a rate of $-213 \pm 29 \mathrm{Gt}^{\mathrm{year}}{ }^{-1}$, of which the figure at Svalbard and Jan Mayen Island was $-9 \pm 5$ Gt year $^{-1}$ (Meredith et al., 2019). Arctic glaciers can store pollution, even that from antiquity (Hong et al., 1994), and thus re-introduction of those pollutants to the environment can become an emerging issue.

This review article concentrates on the European Arctic (Svalbard) and reports on environmental contamination by inorganic pollutants (heavy metals and artificial radionuclides), including their transport pathways, their fate in the Arctic environment and the concentrations of individual elements in the ecosystem. This article presents in detail the secondary contaminant sources, tries to identify knowledge gaps and also indicates needs for further research.
Svalbard-a flagship point in the Arctic

The Svalbard area is believed to be a representative of a typical Arctic critical environment (Dallmann, 2015). Due to the location of its archipelago and easy access, Svalbard is a key place for observing the Arctic environment in general, including the impact of climate change, glaciology, geology or biodiversity. Research in Svalbard is characterized by a high degree of international cooperation (the international research station in Ny- $\mathrm{l}$ lesund, UNIS, SIOS) and is an important flagship site for the European Environment Agency and numerous scientific institutions.

The Svalbard archipelago, situated in the European Arctic, is approximately 57\% covered by glaciers ( $34,000 \mathrm{~km}^{2}$ ), which corresponds to around $10 \%$ of the total area of glaciers in the entire Arctic. The total volume of ice in Svalbard has been estimated to be $6200 \mathrm{~km}^{3}$ (Fürst et al., 2018). Around $60 \%$ of these glaciers (by surface) are tidal glaciers, ending in a fjord or the ocean (Schuler et al., 2020). This type of glacier introduces freshwater into the marine ecosystem through subglacial channels, as well as from submarine melting and the melting of icebergs calved off the glacier fronts. For 20 years, an increasingly fast loss of glacier mass has been observed $(-8 \pm 6 \mathrm{Gt}$ year $^{-1}$; Schuler et al., 2020). Those most sensitive to temperature changes are the thinner and smaller glaciers with a small area of accumulation zone (northern and central Svalbard). In turn, thicker and larger polythermal glaciers, which account for the majority in Svalbard (Nowak et al., 2021), can store, transport and release water even during the winter. Part of the non-glaciarized terrain on Svalbard consists of landforms such as alluvial fans, blockfields, expansive areas with raised marine sediments, colluvial fans covering steeper slopes and sets of beach ridges (Allaart et al., 2021). Intensively melting glaciers are accompanied by a thawing permafrost layer in nonglaciarized areas. In the years 2016-2019, a decrease in the active layer thickness was observed at most of the observation sites in Svalbard (up to $6.5 \mathrm{~cm}_{\text {year }}{ }^{-1}$ in Adventdalen; Moreno-Ibáñez et al., 2021). The primary sources of freshwater to fjords are melting glaciers and sea ice, local rainfall and river runoff. In Svalbard, a large number of rivers are fed by melting glaciers and thawing permafrost. River runoff on Svalbard is highly seasonal-the most significant runoff occurs between May and September-and 
most rivers freeze during the winter period. Considering that river flow in Svalbard depends on an increase in glacier melting, rainfall and the melting of permafrost, it makes rivers there particularly vulnerable to climate change (Moreno-Ibáñez et al., 2021). However, the latest analyses carried out by Nowak et al. (2021) indicate that the catchments with smaller, significantly retreated glaciers, have already reached so-called peak water and are located on the descending section of the runoff curve (e.g. Waldemarelva, Greerelva, Bayelva). On the other hand, catchments affected by larger glaciers-and possibly a more significant part of the non-glaciarized area-are still impacted by increased freshwater runoff (e.g. Adventelva).

Arctic fjords, such as those in Svalbard, are an interface between terrestrial and marine environments and are particularly vulnerable to climate change. These aquatic critical zones (Bianchi et al., 2020) are influenced by glaciers, surface waters and human activities which control the sources, transport and fate of contaminants (Zaborska, 2017; Zaborska et al., 2017).

The major contaminant groups in the Arctic are persistent organic pollutants (POPs), heavy metals and artificial radionuclides (AMAP, 1997). In this paper, we concentrate on inorganic pollutants: heavy metals and radionuclides. Natural sources of heavy metals in the environment include, for example, rock weathering, volcanic eruptions and forest fires. However, the highest emission of metals to the environment is caused by human activities. The most important anthropogenic sources include coal and waste combustion, heat and power plants, transport and the metallurgical and chemical industry (Liu et al., 2018). It has been proven that most of the metals present in the atmosphere over Svalbard are emitted in Europe and Russia (Ardini et al., 2020; Isaksen et al., 2016). The largest sources of anthropogenic radionuclides are global fallout from nuclear tests carried out in the 1950s and 1960s, nuclear fuel processing in Western Europe (Sellafield, Cape La Haque), the Chernobyl power plant disaster (1986) and nuclear installations and waste dumps in the Arctic (Novaya Zemlya) and within the catchment areas of the $\mathrm{Ob}$ and Yenisei rivers (Łokas et al., 2013). In addition, there is also some pollution of local origin, e.g. from coal mining
(Khan et al., 2017), sewage discharge (Kalinowska et al., 2020) and transport (Zhan et al., 2014).

The problem of environmental contamination in Svalbard is becoming more important nowadays in a time of ongoing climate change. It is estimated that the climate on the west coast of Spitsbergen is warming more than six times faster than the global average (Wawrzyniak \& Osuch, 2020). Global environmental changes not only contribute to changes in pollution transport pathways but also lead to an increase in the fluxes of pollutants entering the Spitsbergen aquatic environments from so-called secondary sources of pollution, e.g. melting glaciers, thawing permafrost or rivers (Kohler et al., 2007; Zaborska, 2017; Zaborska et al., 2017).

\section{Heavy metal and radionuclide transport pathways}

Contaminants enter the Svalbard ecosystem from multiple sources. The most important are longrange pathways (atmospheric circulation, ocean currents, riverine transport and ice drift) and local pathways (e.g. coal mining). Moreover, releases from secondary sources (melting glaciers, thawing permafrost, riverine runoff and sea ice melting) lead to increased concentrations in aquatic environments.

Long-range contamination pathways

\section{Heavy metals}

Of all the distant transport paths, air circulation is the fastest way to transfer contaminants to Svalbard from other regions of the world. Heavy metals of anthropogenic origin directly enter the atmosphere in the form of aerosols and particles. They are then transferred by atmospheric circulation to and over the Arctic and can then be released by dry deposition or precipitation, as well as during direct air/water/ice exchange (Durães et al., 2018). Heavy metal air concentrations regularly monitored on Svalbard by the Norwegian Institute for Air Research (NILU) have indicated smaller or larger decreases in the Arctic. Emissions of lead, mercury and cadmium decreased by $65 \%, 13 \%$ and $55 \%$ 
respectively from 1991 to 2019 at the Zeppelin Station (Spitsbergen) (Bohlin-Nizzetto et al., 2019).

Ocean currents are another pathway for transport of heavy metals directly into the Spitsbergen (Svalbard) marine environment, especially for dissolved heavy metals (e.g. Cd, Pb) (Gobeil et al., 2001; Maccali et al., 2013). It has been found that marine current transport of soluble contaminants from Europe to Svalbard takes about 5 years (Dahlgaard, 1995).

Heavy metals may also enter the Spitsbergen (Svalbard) via riverine runoff. The largest rivers discharging freshwater to the Arctic are the Yenisei, Lena and $\mathrm{Ob}$. Rivers carry a substantial amount of pollutants leached out from industrial areas, e.g. the Siberian Chemical Combine. It is estimated that the average annual inflow from the nine largest rivers to the central Arctic Basin is around $2000 \mathrm{~km}^{3}$ year $^{-1}$. Krickov et al. (2019) published the concentrations of trace elements in the suspended matter of 33 Siberian rivers. The metal concentrations found were very variable and exceeded the natural background concentrations: for example, Cd levels were $0.1-1.2 \mathrm{mg} \mathrm{kg}^{-1}$, levels of As were $1-95 \mathrm{mg} \mathrm{kg}^{-1}$ while $\mathrm{Pb}$ levels were $5-45 \mathrm{mg} \mathrm{kg}^{-1}$. Stein (2008) stated that up to $90 \%$ of heavy metals associated with particles transported along with river runoff settles in estuaries, though dissolved metal fractions are transported away from rivers.

The last major contaminant transport pathway is a drift of sea ice. This concerns material incorporated into sea ice during its formation as well as contaminants deposited directly on such ice from the atmosphere. Sea ice formed mainly at Siberian coasts is transported by the Transpolar Drift Stream, within 2-4 years, to the European Arctic (Pavlov et al., 2004; $\mathrm{Su}$ et al., 2019). Tovar-Sánchez et al. (2010) identified significant concentrations of heavy metals (especially $\mathrm{Fe}$ and $\mathrm{Zn}$ ) in Arctic ice and suggested that ice melting is a significant source of pollutants. This theory has also been confirmed by the latest research conducted by Zaborska et al. (2020) on the sea ice in Hornsund (Spitsbergen, Svalbard).

\section{Artificial radionuclides}

The fastest way of transporting radionuclides, as with other pollutants, is through air circulation. Monitoring of radionuclides in the atmosphere is not so systematic, though accidental increases in radionuclide levels associated with accidents, such as in Chernobyl, or related to natural causes such as forest fires have been identified (AMAP 2016).

Long-range transport to Spitsbergen (Svalbard) by marine currents (the Norwegian Atlantic Current and the Norwegian Coastal Current) is the most important means for transport of soluble, conservative radionuclides (e.g. ${ }^{99} \mathrm{Tc},{ }^{137} \mathrm{Cs}$ ) (Brown et al., 1999; Johannessen et al., 2010). The transport of radionuclides within the Arctic has been constantly studied and modelled by the Norwegian Radiation and Nuclear Safety Authority (DSA). Moreover, numerical models simulating transport in the marine environment are constantly being improved since the pioneering work of Prandle (1984), where the fate of ${ }^{137} \mathrm{Cs}$ was simulated after being released from the Sellafield nuclear reprocessing plant (Periáñez et al., 2019).

Riverine concentrations of artificial radionuclides are subject to large fluctuations, depending on the current global situation: for example, the highest radionuclide levels were achieved after the explosion at the Chernobyl power plant (AMAP, 2004).

Multiyear sea ice has been found to transport radionuclides (e.g. Dethleff et al., 2000; Masque et al., 2007; Pavlov \& Stanovoy, 2001). Masque et al. (2007) focused on the sources, fate and time scales of radionuclide transport by sea ice and suggested a need for more thorough research, as sea ice may be an important transport medium for contaminants, and also a secondary source. These studies were later continued by Cámara-Mor et al. (2010, 2011, 2012).

\section{Local sources}

\section{Heavy metals}

Local sources of heavy metals in Svalbard are coal mines (Tolvanen et al., 2018), pollution from human activity, sewage (Hop et al., 2001; Kalinowska et al., 2020), leachate from landfills, coal combustion in power and heat plants (Khan et al., 2017; Rose et al., 2004) and harbours and coal transshipment docks (Van den Granberg et al., 2017; Heuvel-Greve et al., 2016). The last source includes transport and developing tourism is nowadays becoming an important local source (Eckhart et al., 2013; Zhan et al., 2014). Other sources of heavy metals in the Arctic, which can be delivered into Svalbard ecosystems along with long-range 
transport, are metal $(\mathrm{Pb}-\mathrm{Zn})$ mines in Greenland (Johansen et al., 1991; Elberling et al., 2002; Perner et al., 2010) and metal ore mining in northern Russia (Walker et al., 2003; Tkatcheva et al., 2004) and Europe (Heikkinen et al., 2002; Sternal et al., 2017).

\section{Artificial radionuclides}

Local sources of radionuclides in Svalbard were mining operations in the neighbourhood of Ny-Alesund (Dowdall et al., 2004). Currently, there are no sites in the territory of Svalbard that could directly introduce radionuclides in significant amounts into the environment. Other sources that may affect the Svalbard ecosystem are dumped radioactive materials and old submarines on Nowaya Zemlya island and the Kola peninsula (Baskaran et al., 1996; Smith et al., 2000), nuclear weapons tests and occasional radioactive isotope accidents (e.g. Chernobyl; Cwanek et al., 2020).

\section{Secondary sources-remobilization of contamination}

The process of secondary contamination is associated with the re-release of contaminants previously deposited on the surface of the land, glaciers and/ or surface waters. In this era of climate change, this process occurs with the melting of ice, glaciers and snow cover, thawing of permafrost, increased discharge of river runoff or extensive coastal erosion. Taking into consideration the increase in global temperature, and the related increasing rate of melting of glaciers and the increased amount of flowing river water, this phenomenon could have a significant impact on the hydrology and hydrodynamics of fjords, on sediment and contaminant flux and consequently on marine flora and fauna (Kim et al., 2020; Mohan et al., 2018; Zaborska et al., 2017, 2020). Research on secondary pollution of the Arctic environment has been carried out by, among others, Zdanowicz et al., (2013; Baffin Island (Canada)), Søndergaard et al., (2015; Northeast Greenland), Schuster et al., (2018; Alaska), Lim et al., (2020; West Siberia) and Perryman et al., (2020; Alaskan soils). In the case of Spitsbergen, this is a relatively new topic, and research related to secondary pollution sources in this area has only recently been conducted. The impact of environmental changes on the environment of Spitsbergen has been noticed, among others by Birks et al. (2004) for Spitsbergen lakes, Zaborska et al. (2017), Zaborska (2017) and Pouch et al. (2017, 2018, 2021) for marine sediments and Zaborska et al. (2020) for seawater. Mohan et al. (2018) investigated the effect of glacier melting waters on bottom sediments in Kongsfjorden while Johansen et al. (2021) concentrated on riverine suspended particulate matter (SPM) and marine sediments in Isfjorden. Isakson et al. (2003) examined ice cores collected at two stations in Svalbard (Lomonosovfonna and Austfonna) for historical contamination content (mainly organic). They pointed out the possible danger of pesticides being released into the aquatic environment along with melting ice and the dissociation of such compounds.

Several types of glacier are present on Svalbard: ice caps, land terminating valley glaciers and tidewater valley glaciers that flow down directly to the ocean (Fig. 1). Valley glaciers have two zones: the so-called accumulation zone, in which the mass of snow accumulates, and the second-the ablation zone-where the glacier loses its mass due to erosion, wind forces, precipitation, calving and melting (Chu, 2014). Airborne contaminants accumulate on the surface of glaciers via dry and wet deposition. In late spring and summer, water from accumulated snow and glacier ice melting channelizes into supraglacial streams and ponds (Fig. 1) (Chu, 2014). In the glacier ablation zone, meltwater drains through moulins, providing an influx of water into englacial and subglacial environments. In tidewater glaciers, subglacial meltwater conduits directly enter marine water at the level of the glacier base and through the underwater gates localized at the glacier front. Glacier meltwater is enriched in natural rock/soil material from bedrock erosion but also includes airborne material previously deposited at the glacier surface. Thus, contaminants of atmospheric origin accumulated at the glacier surface are transferred into the marine environment. Higher temperatures enhance the melting of not only seasonally formed snow cover but also of old glacier ice. Previously formed glacier ice can contain contaminants that have been accumulated at the glacier surface over the last century (Cogley et al., 2011; Spolaor et al., 2021). In a recent study, Mohan et al. (2018) showed the retreat of glaciers as a result of global warming and, with it, an increase in the runoff of meltwater containing high quantities of suspended solids in Kongsfjorden. They analysed the sedimentation rate 


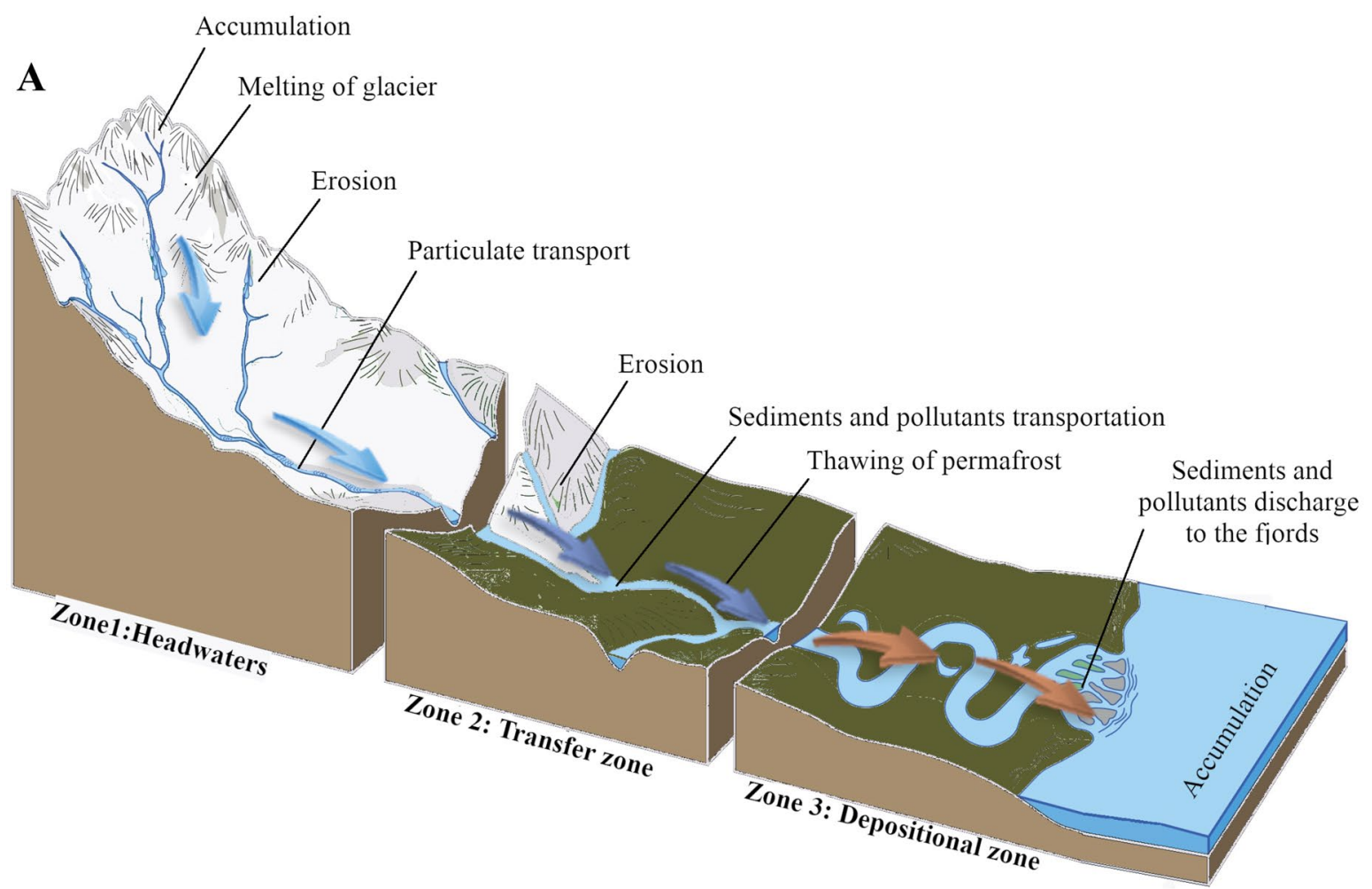

B

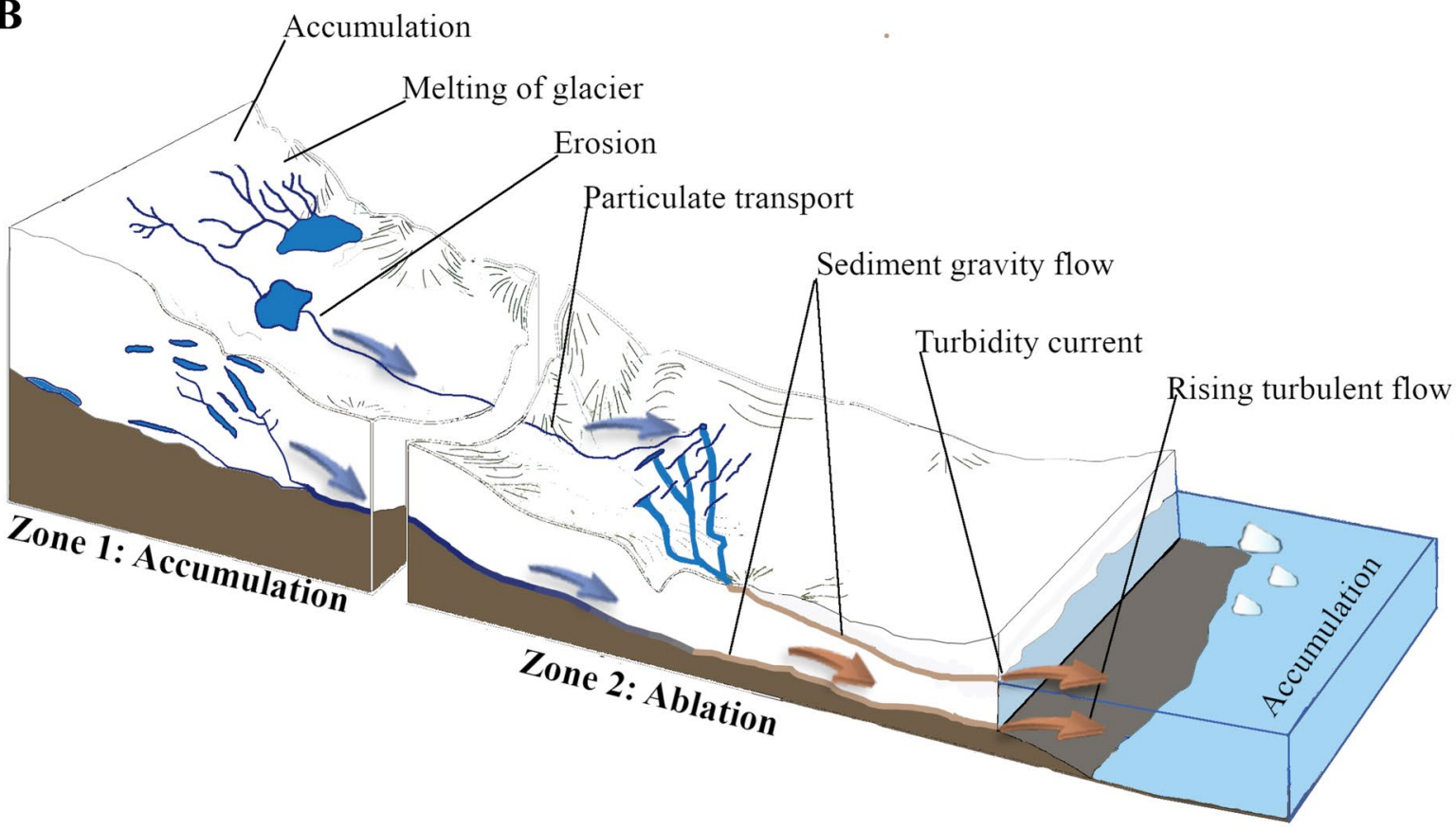

Fig. 1 Secondary sources of contaminants to an Arctic fjord. A Melting land terminating valley glacier and thawing permafrost feed river. B Tidewater glacier delivers meltwater directly to fjord seawater by meltwater runoff and frontal ablation (based on Chu, 2014) 
in the inner fjord and it showed an increase over the last 20 years.

Research conducted by, for example, Węsławski et al. (1995), Beszczyńska-Möller et al. (1997), Hagen et al. (2003) and Błaszczyk et al. (2019), confirms that glaciers are the main source of freshwater supplied to the Spitsbergen fjords. The latest research by Błaszczyk et al. (2019) indicates that the average freshwater supply to Hornsund from tidewater glaciers is $257 \pm 82 \mathrm{Mt} \mathrm{year}^{-1}$, with as much as $39 \%$ (986 Mt year ${ }^{-1}$ ) coming from glacier meltwater runoff and $25 \%$ (634 Mt year ${ }^{-1}$ ) from frontal ablation of tidewater glaciers. Snowfall in winter, rainfall and melting of snow cover represent $21 \%, 7 \%$ and $8 \%$ respectively, which seems to be a small contribution to the total freshwater load. Glacier ablation leads to enhanced pollution discharge from the glaciers to the marine environment (Cogley et al., 2011).

Fjord seawater receives enormous amounts of freshwater directly from melting glacier calving and underwater gates in the glacier front, as well as indirectly via river runoff. These rivers are fed by mountain glacier meltwater, snow melting, permafrost thawing and precipitation (St Pierre et al., 2018). It is estimated that, along with climate change, for every $2{ }^{\circ} \mathrm{C}$ increase in temperature, there will be a $22 \%$ increase in the sediment supply carried by rivers. For every $20 \%$ increase in water discharge in rivers, there will be a $10 \%$ increase in particulate load (Zajączkowski et al., 2004) which may lead to an increase in the flow of secondary pollutants in some regions of Svalbard (Kim et al., 2020). Very few studies have been carried out on the Svalbard rivers, though Bogen and Bonsnes (2003) focused on the erosion process and sediment transport along with the river runoff of Endalselva, Bayelva and Londonelva. An estimation of the variability of water/suspension (and potentially contaminant) discharge by Svalbard rivers would be very interesting, as Ye et al. (2009) and Song et al. (2019) indicated relationships between hydrological regimes and permafrost thawing in large Arctic rivers. The importance of sedimentary material discharge by a Svalbard river (Adventelva) was pointed out by Zajączkowski et al. (2004). McGovern et al. (2020) have recently shown, based on a study of Adventelva, that riverine discharge actually drives the distribution of substances within a fjord. A study by Kim et al. (2020) on total mercury concentrations transported with suspended solids to bottom sediments, in Spitsbergen fjords (Wijdefjorden,
Dickonfjorden and Hornsund), suggests that rivers may increase the concentration of inorganic pollutants in the fjords' marine ecosystem. Recent research by Johansen et al. (2021) on persistent organic pollutants in Isfjorden suggests, however, that the increased inflow of SPM from land may lead to the dilution of pollutants in coastal sediments while affecting their bioavailability in the marine food web.

Other minor processes leading to secondary contamination of Svalbard coasts include transport of metals of anthropogenic origin associated with marine aerosols (Kozak et al., 2015; Lüdke et al., 2005; Samecka-Cymerman et al., 2011). Marine air masses contain sea salt particles enriched in heavy metals due to fractionation in the sea-surface microlayer. It has been found that heavy metals originating from air mass transport prevail in the spring season while sea salt particle generation has higher importance in the summer and autumn (Shevchenko et al., 2003).

An interesting phenomenon concerns the transfer of pollutants by migratory bird species. This was first noticed at seabird colonies in Bjornøya by Evenset et al., (2004, 2007). Seabirds feed on marine species and then-through excretion-redistribute the contaminants to the terrestrial environment. This process was then confirmed by Kristiansen et al. (2019) who studied bird colonies in Kongsfjorden. Moreover, migratory species can transfer contaminants from highly contaminated wintering areas to the Arctic. PacynaKuchta et al. (2020) and Albert et al. (2021) found that migratory birds travelling over long distances can transport toxic substances and via excretion introduce them into the Arctic. They indicated that the Hg concentrations in the bodies of birds in the non-breeding period were several times higher than those found in seabirds breeding in the West Atlantic. The Hg concentrations in the feathers of those birds reached a threshold at which adverse effects on the organism are observed.

Another pathway for secondary pollution of Svalbard shore waters is coastal erosion. Zagórski et al. (2015) found that coastal erosion is a significant process changing the coast of Isbjørnhamna (Hornsund, Svalbard). The coastal area during the observation (1960-2011) decreased by over 31,600 m². An analysis by Wojtysiak et al. (2018) showed that the most intense storms occur in spring and autumn. Due to climate change, storms may occur more frequently 
and become stronger, and thus coastal erosion may become a more important secondary pollution source (Kim et al., 2020).

Groundwater discharge can also be an important source of pollution, as it has been shown to be an important source of nutrients, heavy metals and major ions to rivers and oceans (Webb et al., 2018). In the rapidly warming Arctic permafrost, thawing can intensify groundwater flow (Lecher, 2017; Nowak et al., 2021). In areas with contaminated soil and groundwater, increased groundwater flow may be significant for the functioning of the aquatic ecosystem (Evengard et al., 2011; Nowak et al., 2021).

\section{Fate of inorganic pollutants in the Arctic environment}

The distribution of inorganic pollutants is influenced by transport from remote and local sources but is also modified by local conditions in the Arctic environment (Zaborska et al., 2017). These local conditions include seasonality of river flow, melting glacier discharge, intensity of permafrost thawing, precipitation, oceanic circulation, sediment re-suspension rates, composition of suspended matter/sediments and/ or the presence of living organisms (Paquin et al., 2003; Stern et al., 2012). Once in the marine environment, the fate of heavy metals and radionuclides depends on their form (dissolved or sorbed on particles). During sedimentation, pollutants can be taken up by marine organisms and cycle in the trophic chain (Fig. 2). Heavy metal and radionuclide accumulation have been found to occur in many Arctic marine organisms (Braune et al., 2005; Campbell et al., 2005; Heldal et al., 2013; Rissanen et al., 1997). Moreover, some metals, e.g. $\mathrm{Hg}$ and radionuclides like ${ }^{137} \mathrm{Cs}$, have been found to biomagnify in the marine environment (Dietz et al., 2013; Saremi et al., 2018), and thus monitoring of environmental pollutant levels is necessary (AMAP 2016). Contaminants that accumulate at the sea bottom can be available for the benthic community and be reintroducted to the water column-a process which is enhanced by bioturbation and physical sediment mixing (Thibodaux and Bierman, 2003) or be buried and thus excluded from the environmental cycle (Fig. 2).

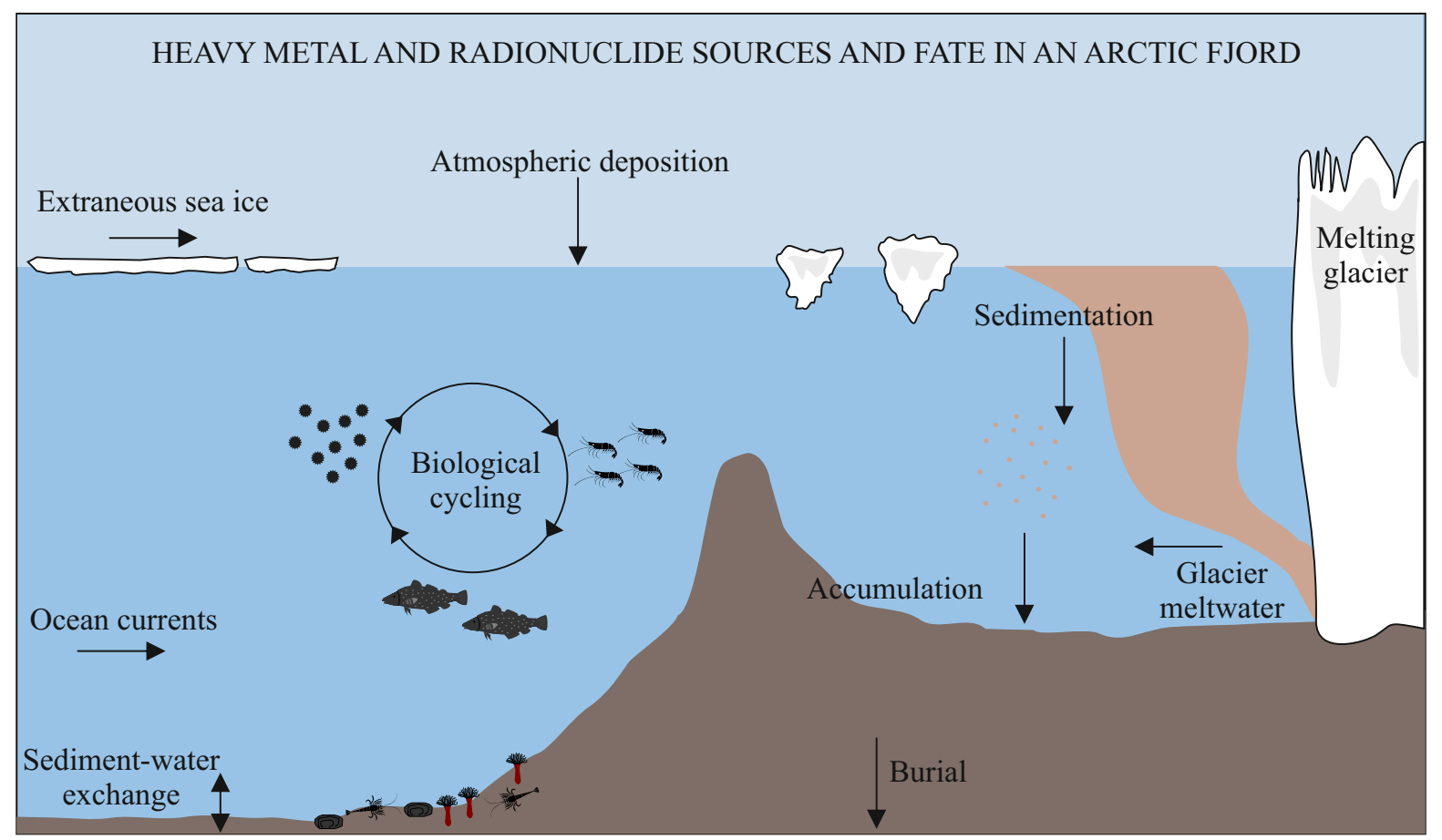

Fig. 2 Sources and fate of heavy metals and radionuclides in an Arctic fjord hosting a tidewater glacier (based on Macdonald \& Loseto, 2010, and Periáñez et al., 2019) 
Heavy metals

Heavy metals in the marine environment can be divided into dissolved and undissolved forms. Dissolved metals are present in the water column and can be transported away from the source by water currents. Due to their high affinity to organic matter and fine mineral particles (Ab Razak et al., 1996), heavy metals adsorb on SPM surfaces.

The forms of such heavy metals depend mainly on the chemical characteristics of the metal and certain environmental properties $(\mathrm{pH}$, redox, oxygen content, salinity). When environmental conditions change the form of the heavy metal can also change (AMAP, 2005). This is very visible in the case of metals deposited in marine sediments that are subjected to changes of $\mathrm{pH}$ and redox conditions (Solomons \& Forstner, 1984). The $\mathrm{pH}$, redox conditions and oxygen content affect multiple processes, such as metal sorption and desorption, dissolution and binding of carbon-bound metals, formation and degradation of soluble and insoluble complex organometallic compounds, formation and dissolution of hydroxides and oxides, and metal precipitation by $\mathrm{Fe} / \mathrm{Mn}$ oxides (especially in aerobic environments at neutral $\mathrm{pH}$ ), among many others (Ansari et al., 2004). Oxygen is usually present only in the topmost sediment layers and contaminants deposited in deeper layers many years ago are immobile. However, sediment mixing processes caused by animals (bioturbation) or physical processes (e.g. bottom currents) allow oxygen to enter to the lower sediment layers. Sediment mixing may facilitate re-mobilization of contaminants and their re-introduction to sediment pore waters and subsequently the water column (Thibodeaux \& Bierman, 2003) and may induce changes of chemical form from less bioavailable to more. Thus, bottom sediments that have been a sink for contaminants for the last century may now become sources of them (Vintró et al., 2002).

Most studies related to this matter indicate that the toxicity of inorganic contaminants increases with decreasing salinity (Hall \& Anderson, 1995; Ytreberg et al., 2011). Heavy metals (e.g. Cd, Hg, Zn) are more bioavailable at lower salinity due to the presence of free metal ions. Increasing salinity decreases the dissolved concentrations of metal ions due to the precipitation of those ions. Thus, in consequence, in more saline waters, the toxicity of metals to organisms is reduced (Park et al., 2014). Ocean waters, due to their higher salinity, have a lower concentration of trace metals, compared to freshwater (Boyle et al., 1974; Hall \& Anderson, 1995; Ytreberg et al., 2011). A detailed review of the fate of $\mathrm{Hg}$ in the Arctic environment was published by Stern et al. (2012). They indicated several processes that may raise the overall net methylation rate of $\mathrm{Hg}$. These include, for example, extending warmer (ice free) periods and increased intensity of introducing carbon and nutrients and sulphates into the marine ecosystem. Moreover, they indicate that increased input of inorganic $\mathrm{Hg}$ from secondary sources (e.g. permafrost thawing, erosion, riverine runoff) would provide more of the mercury substrate required for methylation. On the other hand, an increased photo-demethylation rate and increased MeHg-DOM (dissolved organic matter) binding may reduce the level of $\mathrm{MeHg}$ or absorption through the food web.

Artificial radionuclides

Radionuclides can be divided into non-conservative-primarily adsorbed by solid particles (e.g. plutonium)-and conservative (strontium, caesium, technetium)-which remain dissolved in water and can be transported by water currents (Periáñez et al., 2019). Some radionuclides are also particle-reactive and readily adsorb on SPM and, in consequence, undergo sedimentation to the sea bed.

Changes in radionuclide activity in the marine environment and the prevailing conditions are almost the same as those presented for heavy metals. Progressive climate changes, including an increase in air and water temperature, cause a decrease in the $\mathrm{pH}$ and redox value. Along with decreasing $\mathrm{pH}$, there is increased absorption of carbon dioxide by water and then the production of carbonic acid, causing water acidification. Decreasing the redox value of water causes the formation of the so-called dead zones, which are places with reduced oxygen content (AMAP, 2017). Decreasing $\mathrm{pH}$ and redox conditions also strongly influence the chemical forms of radionuclides (e.g. Pu, Cs). Their different formsoxidation states-distinctly influence their affinity to SPM. For instance, in a reducing environment (low $\mathrm{pH}$, low redox, low oxygen), plutonium exists in oxidation state IV or V (Choppin \& Morgenstern, 2001; Mitchell et al., 1991). Reduced plutonium is highly 
particle reactive and is readily scavenged from the water column to sediments. In an oxidizing environment, $\mathrm{Pu}$ exists in the form of $\mathrm{PuO}_{2}{ }^{+}$and is very soluble in the water column. In this form, it may be transported for long distances and its elimination to marine sediments is very limited.

\section{Concentration of inorganic contaminants in the Svalbard environment- the current state of knowledge}

Heavy metals

Information on trace metal concentrations in the Arctic environment has been gathered by the Arctic Monitoring and Assessment Program since the 1990s (AMAP, 1998). In addition, and at the same time, the Norwegian national monitoring program started measurements of metal concentrations in atmospheric air in Svalbard (Ny-Ålesund) at the Zeppelin station (NILU database). Classification of heavy metal concentrations in sediments, fauna and flora is possible thanks to the Environmental Quality standards (EQS) established by the Norwegian Environmental Protection Agency (M-608,2016; Veileder 02:2018). Other documents enabling the determination of the state of the environment are Environmental Quality Standards given in the EU Water Frame Directive (Lepper, 2005) and Predicted No Effect Concentrations (PNEC) from Risk Assessment Reports available from the EU programme for risk assessment of existing chemicals. A general outline of natural concentrations of heavy metals for rocks of various origins for Svalbard is presented in the literature (Tab. S1). The chemical composition of Svalbard's overbank deposits was mapped by Ottesen et al. (2010). Natural concentrations of heavy metals in the Hornsund parent material were investigated by Samecka-Cymerman et al. (2011). The heavy metal content of coal deposits was investigated by Headley et al. (1996) for Brøggerhalvøya (West Spitsbergen) and by Orheim et al. (2007) for the Longyear and Svea seam. Lu et al. (2012) established trace metal baseline values for surface sediments in Kongsfjorden.

The metal concentration in the Spitsbergen air varies seasonally (Tab. S2). The Norwegian Institute for Air Research (NILU) has monitored air quality since
1989 (Zeppelin station). The latest research containing an analysis of the measured values of heavy metal concentrations in the air at the Zeppelin station is presented in a report by Bohlin-Nizzetto et al. (2019). They showed a slight decrease in the concentration of $\mathrm{As}, \mathrm{Pb}$ and $\mathrm{Hg}$ and an increase in the concentration of $\mathrm{Cu}$ in recent years, compared to 1994. Earlier, e.g. Berg et al. (2004) reported monitoring results of metal concentrations in air at the Zeppelin station from 1994-2002. Only Ni, a metal which is not very toxic, showed a significant downward trend over that time (from 0.19 to $0.07 \mathrm{ng} \mathrm{m}^{-3}$ ), while no significant changes were noticed for other heavy metals. Similar research was conducted later by Conca et al. (2019) in Ny-Ålesund, on the elemental composition of particulate matter PM10. They also indicated the seasonality of the elements' concentrations, an increase during the spring indicating long-distance transport processes (Arctic haze) and an increase in the summer during periods of increased maritime traffic in the fjords. Based on the isotopic composition of $\mathrm{Pb}$, Bazzano et al. $(2015,2017)$ indicated that, in spring, at the time of the highest $\mathrm{Pb}$ air concentration, longrange transport from Eastern Eurasia is the main $\mathrm{Pb}$ source, while in the summer $\mathrm{Pb}$ transport from Northern America prevails.

Elevated heavy metal concentrations have been measured in Spitsbergen soils, e.g. by Negoiţă and Ropotǎ (2000), Gulińska et al. (2003), Melke (2006), Chmiel et al. (2009), Wojtuń et al. (2013), Halbach et al. (2017), Ziółek et al. (2017), Aslam et al. (2019) and Łokas et al. (2019) (Fig. 3, Tab. S3). High levels of heavy metal pollution in soil were found by Negoiţă and Ropotă (2000). Cd, Pb and Cu concentrations were much higher than in other Arctic regions (Greenland and North Siberia). Low concentrations of heavy metals were recorded by Gulińska et al. (2003). The values presented in the article are much lower than for the natural background (Ottensen et al., 2010). However, later studies by Chmiel et al. (2009) and Halbach et al. (2017) showed evident heavy metal contamination in the Scott Glacier Region, Advendalen and Ny-Ålesund. The highest heavy metal concentrations were measured in organically rich soils. The highest concentrations of $\mathrm{Cd}, \mathrm{Pb}, \mathrm{Zn}, \mathrm{Cu}$ (Ziółek et al., 2017) and Hg (Wojtuń et al., 2013) were observed in Wedel Jarlsberg Land, and the highest concentrations of As were in Adventdalen (Aslam et al., 2019). In 


\section{Soils:}

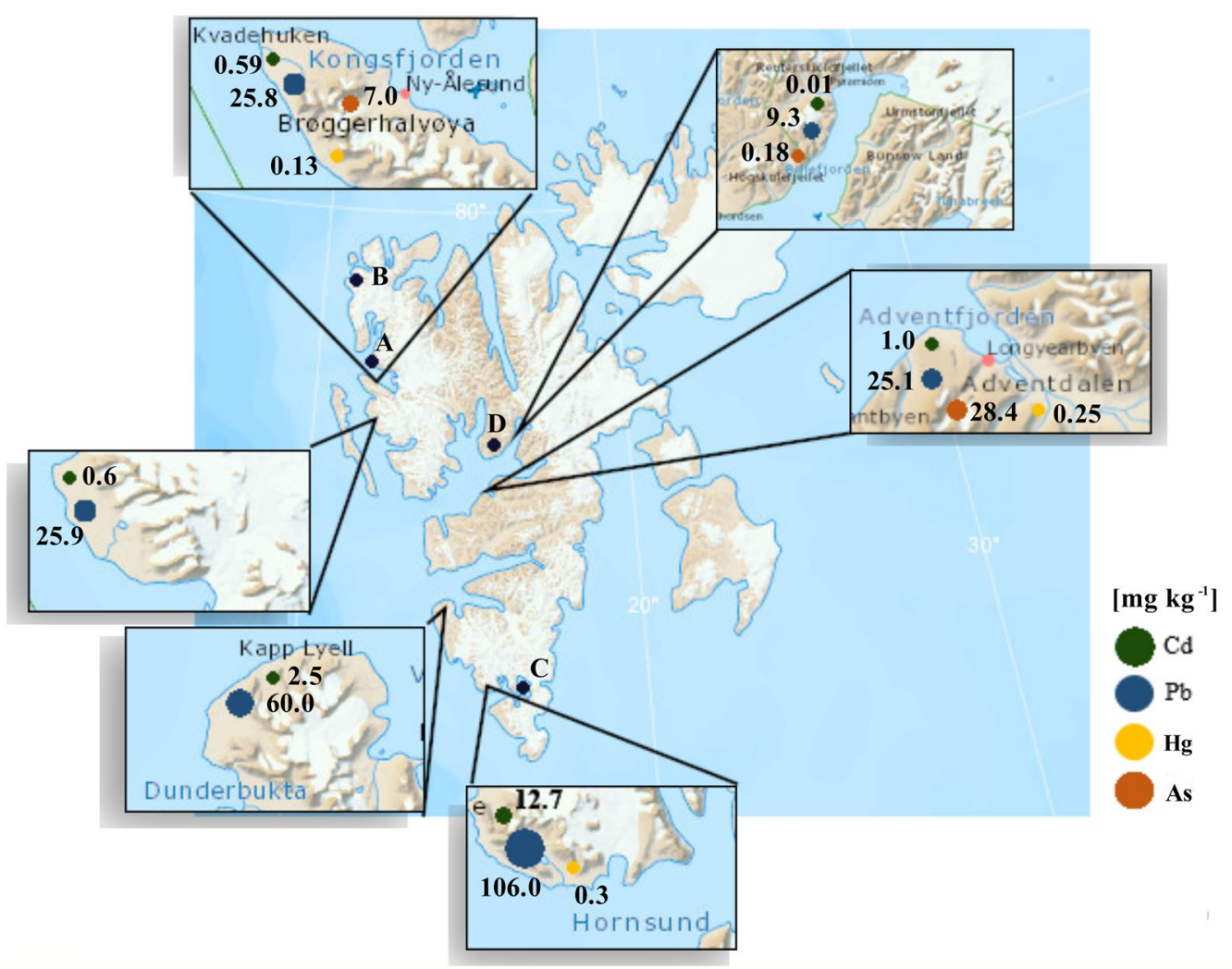

Marine sediments:
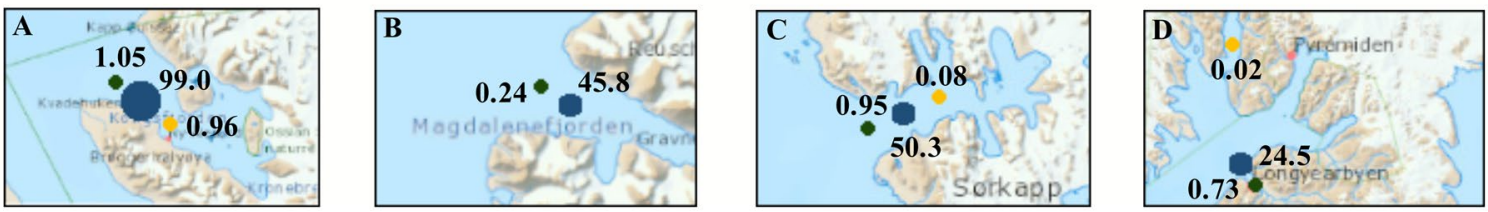

Fig. 3 Maximum concentrations of selected heavy metals in soils and marine sediments of Svalbard (References: Table S3)

addition, there was a noticeable increase in the concentration of heavy metals in the studies conducted by Ziółek et al. (2017), compared to the earlier studies by Wojtuń et al. (2013), in the Wedel Jarlsberg Land region. For comparison, the latest study by Perryman et al. (2020) measured heavy metal pollution in Alaskan soils and obtained much higher values, exceeding the natural background in this region and ranging from $2.0-720 \mathrm{mg} \mathrm{kg}^{-1}$ (mean: $21.1 \pm$ $41.1 \mathrm{mg} \mathrm{kg}^{-1}$ ) for $\mathrm{Pb}, 0.39-14,900 \mathrm{mg} \mathrm{kg}^{-1}$ (mean: $188 \pm 1120 \mathrm{mg} \mathrm{kg}^{-1}$ ) for As and $0.01-6090 \mathrm{mg} \mathrm{kg}^{-1}$ (mean: $30.4 \pm 0.06 \mathrm{mg} \mathrm{kg}^{-1}$ ) for $\mathrm{Hg}$.
Headley (1996) measured increased values of heavy metals $(\mathrm{Pb}, \mathrm{Zn}$ and $\mathrm{Cu})$ in Kongsfjorden peat. Later, historical $\mathrm{Pb}$ enrichment of the peat profile was analysed by Liu et al. (2012). There is a noticeable reduction in $\mathrm{Pb}$ concentration compared to earlier studies by Headley (1996) and in the studied core in 1960-2000. Although the measured $\mathrm{Pb}$ concentrations were not particularly elevated, a clear anthropogenic signal was found based on the isotopic composition of $\mathrm{Pb}$. Studies performed on peat collected close to $\mathrm{Ny}$-Ålesund have shown that $\mathrm{Pb}$ concentrations peaked between 1960 and the 1970s and 
originated from long-range transport from Western Europe and Russia (Liu et al., 2012). As the peat is well above the surrounding mineral soils, the chemical composition of the surface layers in ombrotrophic peatlands depends on atmospheric deposition. Moreover, the peat surface layers are hydrologically isolated from any influence of local waters (surface and groundwater). Therefore, the peat profile can serve as archival stores of the composition of the atmosphere and can thus provide detailed information on the changing rate of metal deposition from the atmosphere (Souter \& Watmough, 2016).

Recently, glacier ice, particularly cryoconites, which are vertical structures on the surface of glaciers, was found to be highly polluted with heavy metals (Singh et al., 2012). The latest studies conducted by Łokas et al., (2016, 2019) indicated an elevated content of heavy metals in these structures (Tab. S3).

Research on heavy metals has also been carried out in terrestrial surface water (Fig. 4; Tab. S4). Drbal et al.
(1992) were one of the first teams to measure the low concentration of heavy metals in SPM from lake water (Linnévatnet) and spring water from a coastal terrace (Petuniabukta). Significantly higher concentrations of $\mathrm{Pb}$ and $\mathrm{Zn}$ were recorded in SPM from the Scott River in later studies by Chmiel et al. (2009). Low concentrations of heavy metals have also been recorded in lake water (Chmiel et al., 2009; Kozak et al., 2015), glacier water in the Scott Glacier region (Chmiel et al., 2009) and rainfall (except Zn; Chmiel et al., 2009; Kozak et al., 2015). There was a high concentration of $\mathrm{Zn}$ (up to $1378 \mu \mathrm{g} \mathrm{L}^{-1}$ ) delivered with rainfall in the Fuglebekken catchment. Low concentrations, not exceeding the natural background, were also recorded in riverine water from the Scott Glacier Region (Chmiel et al., 2009), the Fuglebekken catchment (Kozak et al., 2015) and the Revelva river (Kozak et al., 2016). The highest concentrations of $\mathrm{Cd}$, As and $\mathrm{Zn}$ were recorded in the Revelva River, while the highest concentrations of $\mathrm{Pb}$ and $\mathrm{Cu}$ were in main stream water in the Fuglebekken catchment. Measurements were carried out in the

\section{Water:}

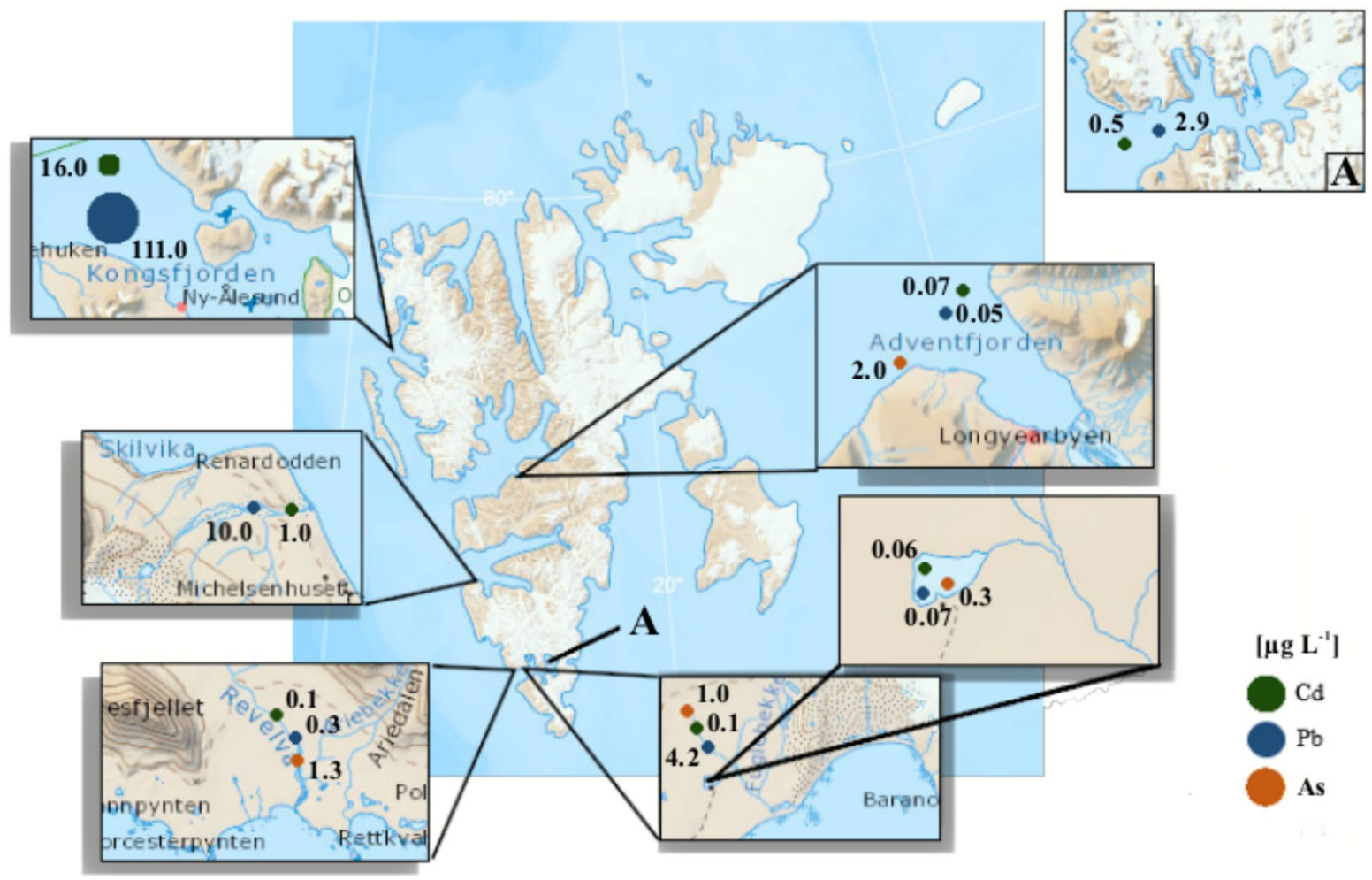

Fig. 4 Maximum concentrations of selected heavy metals in surface waters and seawater of Svalbard fjords (References: Table S4) 
Fuglebekken drainage basin to determine the likelihood that atmospheric precipitation is a supplier of $\mathrm{Pb}, \mathrm{Zn}$ and $\mathrm{Cu}$ to surface waters. The concentration of heavy metals in precipitation arriving from long-distance transport and/or secondary sources, e.g. sea salts, was determined by Kozak et al. (2015).

Heavy metals in lake sediments were studied by Sun et al. (2006). Although metal concentrations were not particularly elevated, temporal concentration differences were clearly noticed in sediment cores (Fig. 3; Tab. S3). The highest heavy metal fluxes were observed in the 1980s and 1990s, and a decrease was noted in the twenty-first century. In contrast, Liu et al. (2012) indicated a current overall increase in $\mathrm{Pb}$ concentrations in lake sediments. This was attributed to climate-sensitive processes (e.g. increased precipitation and meltwater runoff) caused by the warming of the Arctic. Jiang et al. (2011) reported slightly elevated $\mathrm{Hg}$ concentrations, compared to the natural background, in surface lake sediments near Ny-Ålesund. Similar concentrations were measured in other lakes in Spitsbergen: Ossian Sarsfjellet, Ytertjørna, Vassauga and Daltjørna (Drevnick et al., 2012). Gopikrishna et al. (2020) recently analysed sediments collected from three Svalbard lakes for $\mathrm{Hg}$ and $\mathrm{MeHg}$ content. The mean concentrations were comparable to the values in previous studies for other lakes in the Arctic region. That report pointed out that the $\mathrm{Hg}$ in lake sediments was susceptible to $\mathrm{MeHg}$ formation. It was noticed that the process of methylation in lake sediments intensified, as a result of increased primary production caused by temperature increase. Consequently, this high productivity could promote $\mathrm{Hg}$ accumulation in lakes, accelerating the rate of $\mathrm{Hg}$ removal from the water column and subsequent accumulation in bottom sediments (Hudelson et al., 2020; Stern et al., 2012). St Pierre et al. (2018) indicated that glacial rivers are the most important source of $\mathrm{Hg}$ for Lake Hazen (Nunavut, Canada). Moreover, permafrost thawing and erosion significantly increased $\mathrm{Hg}$ concentrations before entering Chandler Fjord waters. That group also identified the potential for increased $\mathrm{Hg}$ concentrations in Arctic ecosystems under the influence of glaciers, as the climate warmed. Klaminder et al. (2010), who researched lead pollution in lakes in the northern part of Sweden, also suggested that the rate of pollution from soil to lakes could increase with climate change.
Typical $\mathrm{Pb}$ concentrations in the seawater of Svalbard, at the end of the twentieth century, ranged from 0.1 to $1 \mu \mathrm{g} \mathrm{L}^{-1}$, while at the Russian Arctic coast and sites near mines in Greenland, these levels even reach $>5 \mu \mathrm{g} \mathrm{L}^{-1}$ (Crane et al., 2001). Seawater Cd concentrations in the Svalbard area oscillated around 0.05-0.1 $\mu \mathrm{g} \mathrm{L}^{-1}$ but higher $\mathrm{Cd}$ concentrations (up to $1 \mu \mathrm{g} \mathrm{L}^{-1}$ ) have been reported for the Russian Arctic coast and Greenland mining sites (Crane et al., 2001). Currently, research on the content of heavy metals in Spitsbergen (Svalbard) seawater has been studied, e.g. by Bazzano et al. (2014), who investigated heavy metal concentrations in the marine water of Kongsfjorden. They found enrichment of metals in the fjord mouth, introduced along with Atlantic waters, particularly at the end of summer (with the highest value inside the fjord, near the Kongsbreen glacier) (Fig. 4; Tab. S3). Research by Kalinowska et al. (2020) focused on the impact of wastewater on water quality in Spitsbergen. They indicated a small impact on heavy metal pollution from urban activities in Longyearbyen town. Cd concentrations were elevated during the summer $\left(0.07 \mu \mathrm{g} \mathrm{L}^{-1}\right)$, which was linked, inter alia, with discharge from the Adventelva river. Zaborska et al. (2020) studied the temporal and spatial variability of the distribution of heavy metals in the Hornsund fjord in Spitsbergen. This research showed that seawater is contaminated with heavy metals (the Cd concentration reached $303 \mathrm{ng} \mathrm{L}^{-1}$ in the particulate fraction and $488 \mathrm{ng} \mathrm{L}^{-1}$ in the dissolved fraction), especially in the summer months. Moreover, it was found that the distribution of heavy metals during the year was modified, inter alia, by meltwater discharges from glaciers, atmospheric deposition and oceanic currents, depending on the season.

Heavy metal concentrations in sea ice (Tab. S4) were elevated along with the Greenland current and Fram Strait (Tovar-Sánchez et al. 2010). The highest concentrations of $\mathrm{Zn}$ and $\mathrm{Cu}$ were observed in the north of Spitsbergen between the parallels of $80^{\circ} \mathrm{N}$ and $81^{\circ} \mathrm{N}$. The latest research by Zaborska et al. (2020) indicated much lower concentrations of these metals in sea ice samples collected in Hornsund.

Several publications have also dealt with trace metal contamination of Spitsbergen fjord marine sediments (Fig. 3; Tab. S3). Most studies conducted so far indicate that the concentration of heavy metals in marine sediments in Svalbard exceeds the natural background values. One of the first studies at the 
beginning of the twentieth century was carried out by Siegel et al. (2000) in Isfjorden and the Western Spitsbergen shelf. The metal concentrations in the shelf sediments were considered to represent natural concentrations. Elevated concentrations in Isfjorden relative to the shelf suggested an initial problem of contamination from anthropogenic activities. Later, Grotti et al. (2013), Lu et al. (2012) and Frankowski \& Frankowska (2014) found elevated metal concentrations in outer Kongsfjorden due to the inflow of Atlantic waters. Bełdowski et al. (2015) studied the concentration of $\mathrm{Hg}$ in bottom sediments of fjords of the western coast of Spitsbergen and in bottom sediments of the Barents Sea. The obtained Hg concentrations are in the range of levels identified in the central Arctic Ocean (0.001-0.12 $\mathrm{mg} \mathrm{kg}^{-1}$ ), in the Beaufort shelf $\left(0.001-0.13 \mathrm{mg} \mathrm{kg}^{-1}\right)$ and along the Greenland coast (0.004-0.28 mg kg-1) (Kirk et al., 2012). A study conducted by Zaborska et al. (2017) indicated clear metal enrichment in some Svalbard fjords (Kongsfjorden, Adventfjorden, Hornsund, Rijpfjorden, Smeerenburgfjorden and Magdalenefjorden). Moreover, based on $\mathrm{Pb}$ isotopic composition, it was found that up to $85 \%$ of $\mathrm{Pb}$ originates from anthropogenic sources, mainly in Russia and Europe but also (particularly in the northern fjords) from North America (Zaborska et al., 2017). Mohan et al. (2018) showed an upward trend in the concentration of metals in cores collected in the inner part of Kongsfjorden and observed a high deposition rate since the 1970s, pointing to the impact of industrial emissions. Choudhary et al. (2020) studied the sediments of the Krossfjorden-Kongsfjorden fjord system to determine the environmental toxicity of metals, as well as their origin, mobility and bioavailability. They identified differences in metal concentrations at sites influenced by both glacial activity and Atlantic water masses. However, rock weathering has been identified as the main source of heavy metals for fjords. A study by Kim et al. (2020) compared the content of total $\mathrm{Hg}$ in surface sediments in three fjords of Spitsbergen: Hornsund, Dicksonfjorden and Wijdefjorden. The total concentration of $\mathrm{Hg}$ associated with organic matter in surface sediments was at its highest in Hornsund, which was attributed to high organic carbon accumulation and intense glacier melting. Recent research by Sagar et al. (2021) indicates significantly increased $\mathrm{Cd}, \mathrm{Pb}, \mathrm{Zn}$ and $\mathrm{Cu}$ concentrations in the outer part of Kongsfjorden, compared to previous research in the region.
Other research has focused on heavy metal concentrations in Svalbard fauna and flora (Tab. S5). Godzik et al. (1991) indicated that the concentration of heavy metals within the moss colony on Hornsund's coast was 1.5-2 times higher than outside the fjord. They believed seabird colonies to be the source of contamination. Much higher $\mathrm{Zn}$ and $\mathrm{Cu}$ concentrations in moss were found in later studies (Samecka-Cymerman et al., 2011) in West Spitsbergen (Wedel Jarlsberg Land). Elevated concentrations of some heavy metals ( $\mathrm{Cd}$ and $\mathrm{As}$ ) were also found in the gonad and intestine of sea urchins, and Laminarian kelps in a later study by Ahn et al. (2009) in Kongsfjorden. Moreover, Jæger et al. (2009) reported low total $\mathrm{Hg}$ and $\mathrm{MeHg}$ levels in Kongsfjorden zooplankton (muscle and livers), polar cod (muscle and livers), seabird (muscle and livers), Capelin (muscle) and herring (muscle). These studies were also confirmed by Ruus et al. (2015), who obtained equally low concentrations of total $\mathrm{Hg}$ and $\mathrm{MeHg}$ for Kittiwake, Little auk, Polar cod, Capelin and plankton in Kongsfjorden. Øverjordet et al., (2015a, 2015b) conducted studies on the heavy metal concentrations in the liver and muscles of the black-legged kittiwake, obtaining significantly higher concentration values compared to other species of animals and plants tested in the Kongsfjorden area. They indicated seasonal variability in the diet of organisms as well as migration and moulting as the reason. In the same year, Øverjordet et al., (2015a, 2015b) published studies on $\mathrm{Hg}$ and $\mathrm{Cd}$ concentrations in Kittiwake and Little Auk while confirming heavy metal contamination of bird in Kongsfjorden and Liedefjorden. The latest research by Pacyna-Kuchta et al. (2020) on little auks in Hornsund also confirmed heavy metal contamination of these organisms, especially in adult birds. Węgrzyn et al. (2016) studied changes in heavy metal concentrations in lichens in the Kaffiøyra Plain (Oskar II Land, NW Spitsbergen) in a transect from the glacier front to the shoreline. They identified the main environmental factors-distance from the shoreline, substrate type and soil $\mathrm{pH}$-which influence heavy metal deposition in lichens. The $\mathrm{Cd}$ content in the lichens was almost equal to that measured in the soil (C. delisei: $0.10-0.29 \mathrm{mg} \mathrm{kg}^{-1}$; soil: $0.12-0.30 \mathrm{mg} \mathrm{kg}^{-1}$ ). More recently, Kłos et al. (2017) also measured the concentration of selected heavy metals in lichen samples. They found high $\mathrm{Ni}$ concentrations in samples taken near Longyearbyen, 
compared to other areas of Spitsbergen, which was attributed to the release of nickel into the atmosphere during coal mining operations in the Longyearbyen area. Węgrzyn et al. (2018) determined the content of selected heavy metals (e.g. $\mathrm{Cd}, \mathrm{Cu}, \mathrm{Fe}, \mathrm{Pb}$ and $\mathrm{Zn}$ ) in reindeer manure. Their main goal was to determine the seasonal variability in heavy metal content in faeces and to compare these values with the nutritional preferences of reindeer throughout the year. They showed lower concentrations of heavy metals in reindeer faeces compared to the concentrations measured in the vegetation they feed on.
Artificial radionuclides

A literature review recently conducted by Ayoub \& Song (2020) includes studies conducted in non-Arctic and Arctic regions which include reference to high precipitation rates and high atmospheric deposition of radionuclides in the Arctic. Moreover, the Arctic was identified as a region with higher radionuclide concentrations compared to other regions (e.g. Antarctica). Figures 5 and 6 present the concentration activities of different artificial radionuclides in various elements of the Spitsbergen environment. The

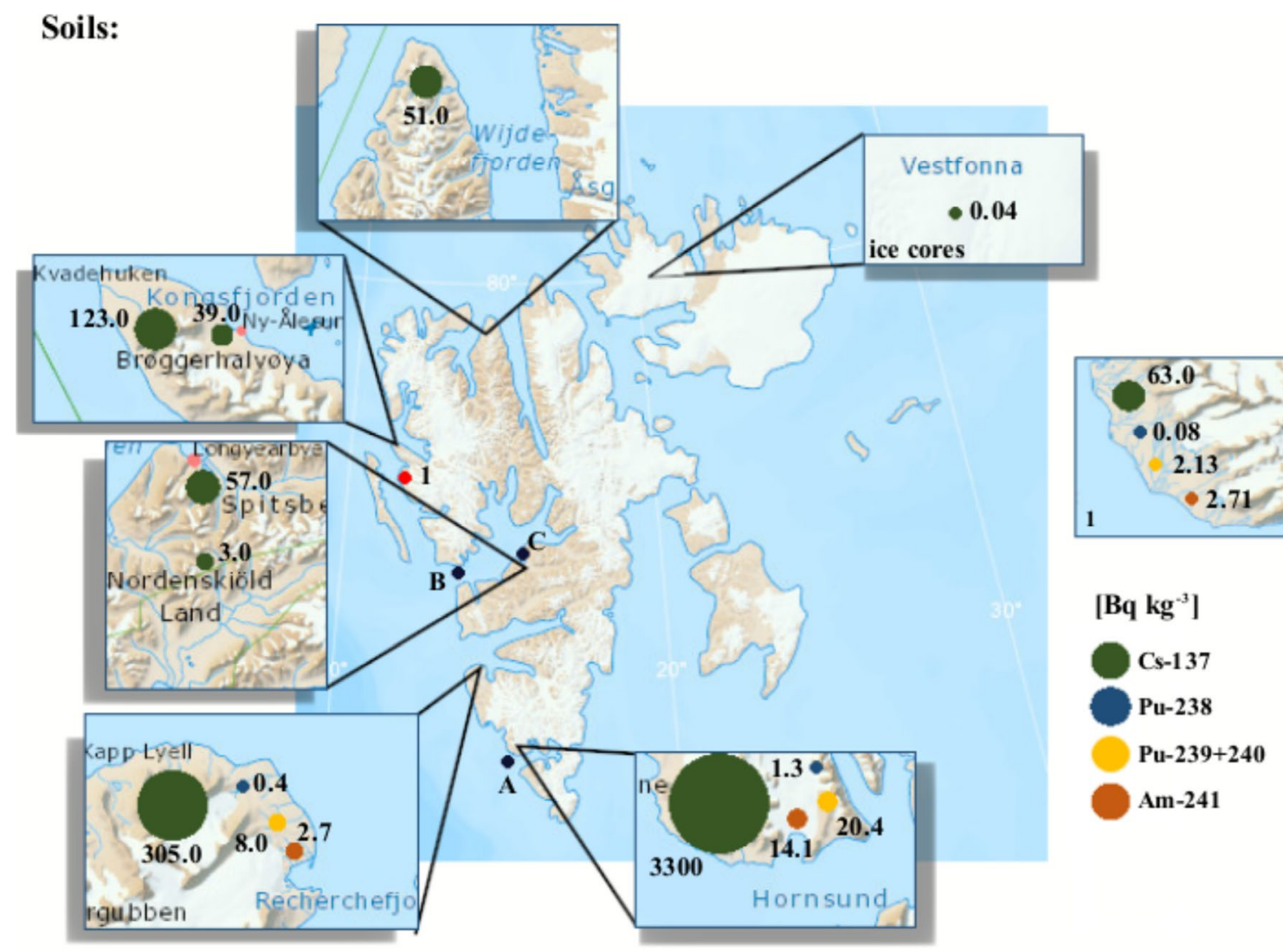

\section{Marine sediments}
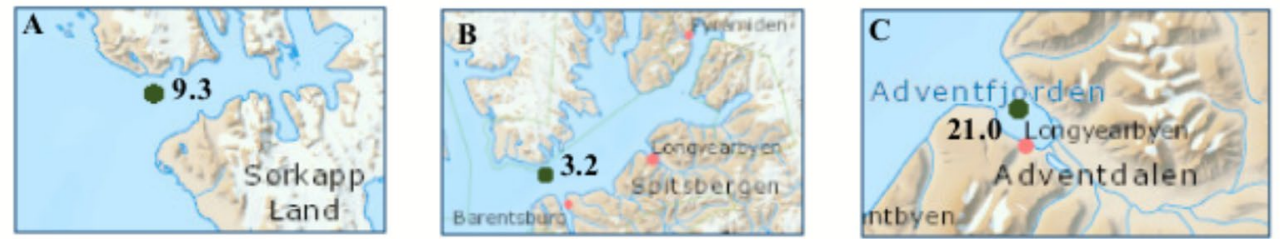

Fig. 5 Maximum activity concentrations of selected radionuclides in soils and marine sediments of Svalbard (References: Table S6) 


\section{Water:}

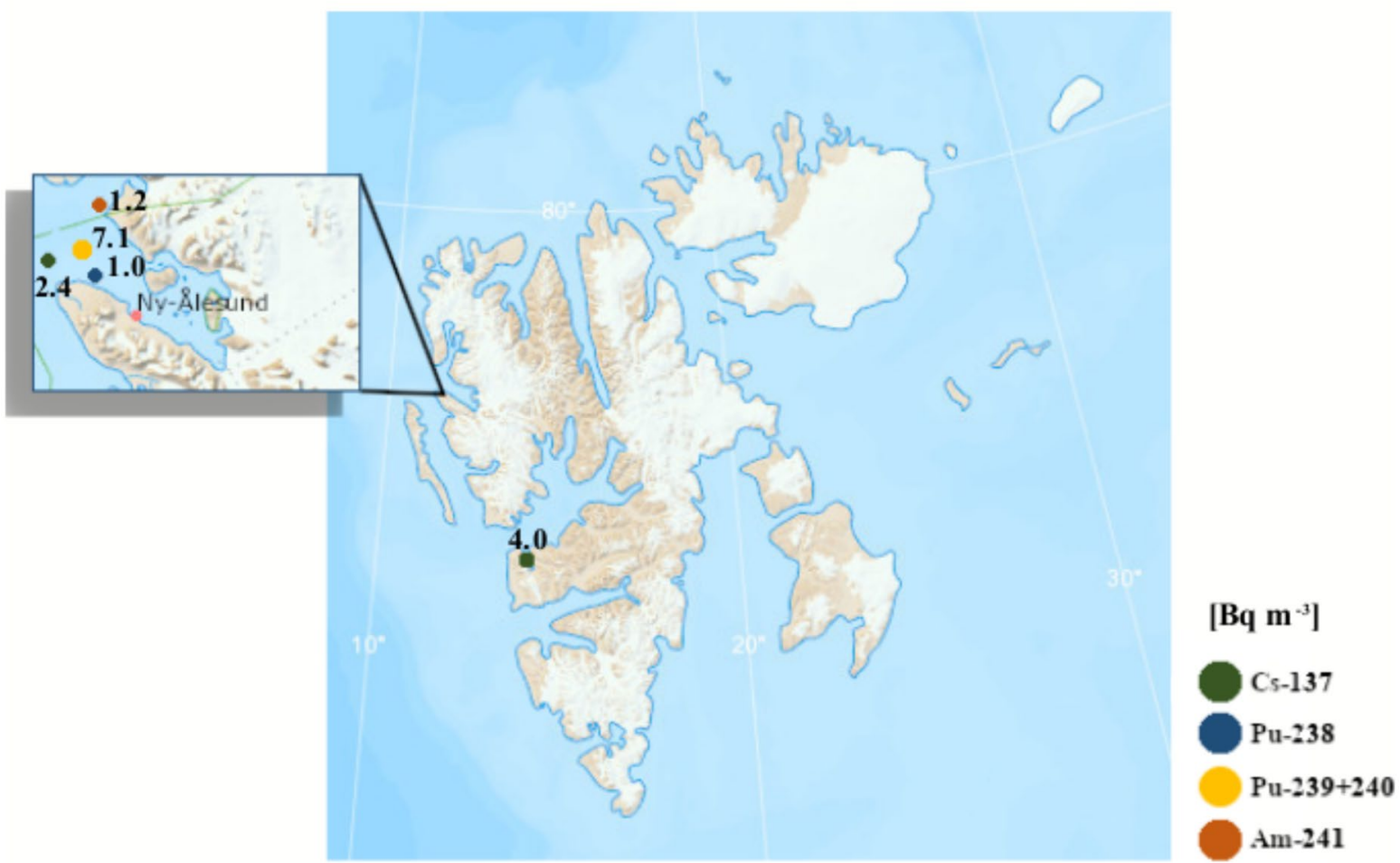

Fig. 6 Maximum activity concentrations of selected radionuclides in seawater in different Svalbard regions (References: Table S7)

concentration of radionuclides in soils was tested by Dowdall et al., (2003, 2004), Gwynn et al. (2004), Chmiel et al. (2009), Łokas et al., (2013, 2017, 2019) and Kłos et al. (2017). The highest concentrations of ${ }^{137} \mathrm{Cs},{ }^{238} \mathrm{Pu},{ }^{239+}{ }^{240} \mathrm{Pu}$ and ${ }^{241} \mathrm{Am}$ were recorded in Werenskioldbreen (Fig. 5, Tab. S6). Dowdall et al. (2003) indicated that bird droppings could be the main source enriching the soil with radionuclides in Kongsfjorden. These studies were continued and also showed soil contamination with radionuclides from coal mining at Svalbard (Dowdall et al., 2004). The authors found enrichment in natural radionuclide levels caused by anthropogenic activity in the form of coal mining processes (e.g. ${ }^{238} \mathrm{U}$ ). Research conducted by Łokas et al., (2013, 2019) was carried out in tundra and proglacial zones of mountain glaciers on Svalbard. The activity concentration results showed a very wide range from almost undetectable to extremely high, which was linked to melting of highly enriched cryoconites. Soils of proglacial zones of the Werenskiold Glacier were also found to contain extremely elevated radionuclide activity concentrations, due to melting of glacier ice containing cryoconites (Łokas et al., 2017). Studies on soil radionuclide activity concentrations were conducted by Kłos et al. (2017) near Longyearbyen (Spitsbergen) and indicated that sea aerosols may be an important ${ }^{137} \mathrm{Cs}$ source.

Pinglot et al. (1999) examined ${ }^{137}$ Cs activity concentrations in the glacier ice of Svalbard (Kongsvegen, Snøfjella, Vestfonna, Austfonna, Lomonosovfonna and Asgardfonna) (Tab. S6). Radionuclide contamination was found mainly in the reference layers from the Chernobyl nuclear plant explosion and nuclear tests in the 1960s. Łokas et al. (2016) indicated increased activity of radionuclides in cryoconites on the surface of the Hans Glacier in Hornsund. These studies were continued in the cryoconites of the Werenskioldbreen Glacier by Łokas et al. (2017), where activity concentrations for ${ }^{137}$ Cs were much higher than in Hans Glacier. Recent research by Łokas et al. (2019) in the Kaffiøyra region shows 
activity concentrations of ${ }^{137} \mathrm{Cs},{ }^{238} \mathrm{Pu},{ }^{239+{ }^{240} \mathrm{Pu} \text { and }}$ ${ }^{241} \mathrm{Am}$ which indicate higher radionuclide contamination of cryoconite compared to Hans Glacier. Moreover, Cota et al. (2006) and Cámara-Mor et al. (2010) reported extremely high radionuclide activity concentrations in sea ice sediments from different sites of the Arctic Ocean (Resolute Bay, the Nansen Basin and the Fram Strait). The activity of ${ }^{137} \mathrm{Cs}$ reached $4 \times 10^{3} \mathrm{~Bq} \mathrm{~kg}^{-1}$ (the Nansen Basin) while ${ }^{239+{ }^{240} \mathrm{Pu}}$ activity concentrations reached $42 \mathrm{~Bq} \mathrm{~kg}^{-1}$ (Resolute Bay).

Appleby (2004) examined ${ }^{137}$ Cs levels in lake sediments from eight lakes located on the west coast of Svalbard, as part of a project dedicated to the investigation of atmospheric pollution and environmental changes in the Arctic (Fig. 5; Tab. S6). He found out that the total activity concentration of deposited ${ }^{137} \mathrm{Cs}$ was very variable and ranged from $715 \mathrm{~Bq} \mathrm{~m}^{-2}$ (Arresjøen) to $5032 \mathrm{~Bq} \mathrm{~m}^{-2}$ (Daltjørna).

Gerland et al. (2002) measured ${ }^{99} \mathrm{Tc},{ }^{137} \mathrm{Cs},{ }^{238} \mathrm{Pu}$, ${ }^{239}+{ }^{240} \mathrm{Pu}$ and ${ }^{241} \mathrm{Am}$ levels in marine water, sea ice and seaweed collected in Kongsfjorden and in Greenland and Barents seawater. Gwynn et al. (2004) studied radionuclide contamination of seawater (Fig. 6, Tab. S7). They showed a decrease in ${ }^{137} \mathrm{Cs}$ activity concentration to a level which was a factor of 10 lower than that found in the 1980s, which indicates a reduction in discharge of this radionuclide. Based on radionuclide activity ratios, it was found that global fallout from the atmosphere is the dominant radionuclide source. Radionuclide concentrations were measured in different marine environment components (seawater, sediments and biota) of West Spitsbergen by Leppänen et al. (2013). Generally, low ${ }^{137} \mathrm{Cs}$ and ${ }^{90} \mathrm{Sr}$ activity concentrations are reported for Western Spitsbergen shelf water (Leppänen et al., 2013). In 2020, the latest report was published indicating the concentration of artificial radionuclides in Norway and Svalbard. It presents the results of research on radionuclide concentrations in seawater. The results for ${ }^{137} \mathrm{Cs}$ (Ny-Ålesund) presented in the report were lower than in previous studies (Skjerdal et al., 2020).

Research conducted by Heldal et al. (2002) showed quite low pollution of marine sediments with radionuclides (Tab. S6). However, Zaborska (2017) showed an increased flux of ${ }^{137} \mathrm{Cs}$, indicating the great influence of melting glaciers on the phenomenon of fjord pollution. The load of the artificial radionuclide ${ }^{137} \mathrm{Cs}$ in the vicinity of glacier outflow was 14 times higher than in the central part of the fjord. ${ }^{137} \mathrm{Cs}$ activity concentration was measured to validate sediment dating results by Pawłowska et al. (2017) and earlier by Zajączkowski et al. (2004) in Hornsund and Adventfjorden, and the measured ${ }^{137} \mathrm{Cs}$ activity concentrations were low $\left(0.1-7 \mathrm{~Bq} \mathrm{~kg}^{-1}\right)$.

Radionuclides in marine and terrestrial mammals in Svalbard were presented in a report performed by Gwynn et al. (2005) (e.g. in muscles of ringed seals ${ }^{137} \mathrm{Cs}$ ranged from $0.4-0.6 \mathrm{~Bq} \mathrm{~kg}^{-1}$, while the corresponding value was $0.3-2.7 \mathrm{~Bq} \mathrm{~kg}^{-1}$ in the muscles of Svalbard reindeers). These figures indicate generally low anthropogenic radioactive contamination in fauna and flora. Benthic echinoderms from Isfjorden and Magdalenefjorden were recently studied by Saniewski and Borszcz (2017) (Tab. S8). This study showed increased concentrations of radionuclides in the bodies of benthic organisms. The authors also point to the serious problem of radionuclide bioaccumulation. However, a recent study by Mezaki et al. (2019) on ${ }^{134} \mathrm{Cs}$ and ${ }^{137} \mathrm{Cs}$ in animals and plants showed a lack of radioactivity in most of the samples tested. The low activity of ${ }^{137} \mathrm{Cs}$ was demonstrated for some lichens and mushrooms.

\section{Summary and knowledge gaps}

Heavy metals and radionuclides are undoubtedly important pollutants of the environment that can affect the ecosystems of Svalbard and the Arctic. It is therefore important to constantly monitor their environmental concentrations. Although the release of pollutants from secondary sources has recently been described in the literature, no regular and comprehensive study has been performed. Global climate change, melting glaciers, thawing permafrost or increased riverine runoff can lead to the release of pollutants previously deposited on surfaces and increase the load of inorganic pollutants in the marine environment. Significant scientific advances have been made regarding the effects of climate change on the fate of inorganic pollutants in the Arctic, and these advances show increased discharge of metals (e.g. mercury from melting permafrost and glaciers). Although there are some empirical data to support the conceptual predictions presented by Macdonald et al. in 2005, for example Stern et al. (2012), Mohan et al. (2018) and St Pierre et al. (2019), there is still 
no complete picture of the environmental fate of inorganic contaminants, especially radionuclides, in Svalbard. Contamination of the Arctic environment by organic substances, particularly new emerging pollutants (e.g. pharmaceutical residues) should also be thoroughly studied.

Acknowledgements The study reports results achieved within the National Science Center project (NCN2015/17/B/ ST10/03390).

Funding The work on this review was financed by statutory IO PAN activities (Theme 2.2).

Open Access This article is licensed under a Creative Commons Attribution 4.0 International License, which permits use, sharing, adaptation, distribution and reproduction in any medium or format, as long as you give appropriate credit to the original author(s) and the source, provide a link to the Creative Commons licence, and indicate if changes were made. The images or other third party material in this article are included in the article's Creative Commons licence, unless indicated otherwise in a credit line to the material. If material is not included in the article's Creative Commons licence and your intended use is not permitted by statutory regulation or exceeds the permitted use, you will need to obtain permission directly from the copyright holder. To view a copy of this licence, visit http://creativecommons.org/licenses/by/4.0/.

\section{References}

Ab Razak, I. A., Li, A., \& Christensen, E. R. (1996). Association of PAHs, PCBs, Cs-137 and Pb-210 with clay, silt and organic carbon in sediments. Water Science and Technology, 34(7-8), 29-35.

Ahn, I.-Y., Ji, J., \& Park, H. (2009). Metal accumulation in sea urchins and their kelp diet in an Arctic fjord (Kongsfjorden, Svalbard). Marine Pollution Bulletin, 58, 1571-1577.

Albert, C., Helgason, H. H., Brault-Favrou, M., Robertson, G. J., Descamps, S., Amélineau, F., Fort, J., et al. (2021). Seasonal variation of mercury contamination in Arctic seabirds: A pan-Arctic assessment. Science of the Total Environment, 750, 142201.

Allaart, L., Schomacker, A., Håkansson, L. M., Farnsworth, W. R., Brynjólfsson, S., Grumstad, A., \& Kjellman, S. E. (2021). Geomorphology and surficial geology of the Femmilsjøen area, northern Spitsbergen. Geomorphology, 382(2), 107693.

Ansari, T. M., Marr, I. L., \& Tariq, N. (2004). Heavy metals in marine pollution perspective-A mini review. Journal of Applied Sciences, 4, 1-20.

AMAP, 1997. Arctic pollution issues: A state of the Arctic Environment Report. Arctic monitoring and Assessment Programme (AMAP), Oslo, Norway. xii+188 pp.

AMAP, 1998. AMAP assessment report: Arctic pollution issues. Arctic Monitoring and Assessment Programme (AMAP), Oslo, Norway. xii+859 pp.
AMAP, 2002. Arctic Pollution 2002: Persistent organic pollutants, heavy metals, radioactivity, human health, changing pathways. Arctic Monitoring and Assessment Programme (AMAP), Oslo, Norway. xii+112 pp.

AMAP, 2004. AMAP Assessment 2002: Radioactivity in the Arctic. Arctic Monitoring and Assessment Programme (AMAP), Oslo, Norway. xi $+100 \mathrm{pp}$.

AMAP, 2005. AMAP Assessment 2002: Heavy metals in the Arctic. Arctic Monitoring and Assessment Programme (AMAP), Oslo, Norway. xvi $+265 \mathrm{pp}$.

AMAP, 2006. AMAP Assessment 2006: Acidifying pollutants, Arctic haze, and acidification in the Arctic. Arctic Monitoring and Assessment Programme (AMAP), Oslo, Norway. xii+112 pp.

AMAP, 2010. AMAP Assessment 2009: Radioactivity in the Arctic. Arctic Monitoring and Assessment Programme (AMAP), Oslo, Norway. xii +92 pp.pp.

AMAP, 2011. AMAP Assessment 2011: Mercury in the Arctic. Arctic Monitoring and Assessment Programme (AMAP), Oslo, Norway. xiv +193 pp.

AMAP, 2016. AMAP Assessment 2015: Radioactivity in the Arctic. Arctic Monitoring and Assessment Programme $(A M A P)$, Oslo, Norway. vii +89 pp.

AMAP, 2019. AMAP Climate Change Update 2019: An Update to Key Findings of Snow, Water, Ice and Permafrost in the Arctic (SWIPA) 2017. Arctic Monitoring and Assessment Programme (AMAP), Oslo, Norway. $12 \mathrm{pp}$.

AMAP, 2017. Snow, Water, Ice and Permafrost in the Arctic (SWIPA) 2017. Arctic Monitoring and Assessment Programme (AMAP), Oslo, Norway. xiv + 269 pp.

Appleby, P. G. (2004). Environmental change and atmospheric contamination on Svalbard: Sediment chronology. Journal of Paleolimnology, 31(4), 433-443.

Ardini, F., Bazzano, A., \& Grotti, M. (2020). Lead isotopic ratios in the Arctic environment. Environmental Chemistry, 17(3), 213.

Aslam, S. N., Huber, C., Asimakopoulos, A. G., Steinnes, E., $\&$ Mikkelsen, Ø. (2019). Trace elements and polychlorinated biphenyls (PCBs) in terrestrial compartments of Svalbard, Norwegian Arctic. Science of the Total Environment, 685, 1127-1138.

Ayoub, A. A., \& Song, Y. (2020). Radioactivity measurement in glacier and Polar ice-caps: an overview. IOP Conference Series: Earth and Environmental Science, 467.

Baskaran, M., Asbill, S., Santschi, P., Brooks, J., Champ, M., Adkinson, D., Colmer, M. R., \& Makeyev, V. (1996). Pu, 137Cs and excess $210 \mathrm{~Pb}$ in Russian Arctic sediments. Earth and Planetary Science Letters, 140(1-4), 243-257.

Bazzano, A., Ardini, F., Terol, A., Rivaro, P., Soggia, F., \& Grotti, M. (2017). Effects of the Atlantic water and glacial run-off on the spatial distribution of particulate trace elements in the Kongsfjorden. Marine Chemistry, 191, 16-23.

Bazzano, A., Ardini, F., Becagli, S., Traversi, R., Udisti, R., Cappelletti, D., \& Grotti, M. (2015). Source assessment of atmospheric lead measured at Ny-Ålesund, Svalbard. Atmospheric Environment, 113, 20-26.

Bazzano, A., Rivaro, P., Soggia, F., Ardini, F., \& Grotti, M. (2014). Anthropogenic and natural sources of particulate trace elements in the coastal marine environment of Kongsfjorden, Svalbard. Marine Chemistry, 163, 28-35. 
Berg, T., Kallenborn, R., \& Manø, S. (2004). Temporal trends in atmospheric heavy metal and organochlorine concentrations at Zeppelin, Svalbard. Arctic, Antarctic, and Alpine Research, 36(3), 284-291.

Bełdowski, J., Miotk, M., Zaborska, A., \& Pempkowiak, J. (2015). Distribution of sedimentary mercury off Svalbard, European Arctic. Chemosphere, 122, 190-198.

Bianchi, T. S., Arndt, S., Austin, W. E. N., Benn, D. I., Bertrand, S., Cui, X., ... Syvitski, J. (2020). Fjords as Aquatic Critical Zones (ACZs). Earth-Science Reviews, 103145.

Beszczynska-Moller, A., Węsławski, J. W., Walczowski, W., \& Zajączkowski, M. (1997). Estimation of glacial meltwater discharge into Svalbard coastal waters. Oceanologia, 39, 289-299.

Birks, H. J. B., Jones, V. J., \& Rose, N. L. (2004). Recent environmental change and atmospheric contamination on Svalbard as recorded in lake sediments - Synthesis and general conclusions. Journal of Paleolimnology, 31(4), 531-546.

Blais, J. M., Schindler, D. W., Muir, D. C. G., Sharp, M., Donald, D., Lafreniere, M., Breakevelt, E., \& Strachan, M. J. (2001). Melting glaciers: A major source of persistent organochlorines to subalpine bow lake in Banff National Park Canada. Ambio, 30(7), 410-415.

Błaszczyk, M., Ignatiuk, D., Uszczyk, A., Cielecka-Nowak, K., Grabiec, M., Jania, J. A., Moskalik, M., \& Walczowski, W. (2019). Freshwater input to the Arctic fjord Hornsund (Svalbard). Polar Research 38.

Bogen, J., \& Bønsnes, T. E. (2003). Erosion and sediment transport in high Arctic rivers, Svalbard. Polar Research, 22, 175-189.

Bohlin-Nizzetto, P., Aas, W., \& Nikiforov, V. (2019). Monitoring of environmental contaminants in air and precipitation. Annual report 2019. Norwegian Environment Agency Postboks 5672 Sluppen, 7485 Trondheim.

Boyle, E., Coller, R., Dengler, A. T., Edmont, J. M., Ng, A. C., \& Stallard, R. F. (1974). On the chemical mass-balance in estuaries. Geochimica Et Cosmochimica Acta, 38, 1719-1728.

Braune, B., Muir, D., DeMarch, B., Gamberg, M., Poole, K., Currie, R., Dodd, M., Duschenko, W., Eamer, J., Elkin, B., Evans, M., Grudny, S., Hebert, C., Johnstone, R., Kidd, K., Koeni, B., Lockhart, L., Marshall, H., Reimer, K., ... Shutt, L. (1999). Spatial and temporal trends of contaminants in Canadian Arctic freshwater and terrestrial ecosystems: A review. The Science of the Total Environment, 230, 145-207.

Braune, B. M., Outridge, P. M., Fisk, A. T., Muir, D. C. G., Helm, P. A., Hobbs, K., Stirling, I., et al. (2005). Persistent organic pollutants and mercury in marine biota of the Canadian Arctic: An overview of spatial and temporal trends. Science of the Total Environment, 351-352, 4-56.

Brown, J. E., McDonald, P., Parker, A., \& Rae, J. E. (1999). The vertical distribution of radionuclides in a Ribble Estuary saltmarsh: Transport and deposition of radionuclides. Journal of Environmental Radioactivity, 43(3), 259-275.

Cámara -Mor, P., Masque, P., Garcia-Orellana, J., Cochran, J. K., Mas, J. L., Chamizo, E., \& Hanfland, C. (2010). Arctic Ocean sea ice drift origin derived from artificial radionuclides. Science of the Total Environment, 408(16), 3349-3358.

Cámara -Mor, P. , Masque, P. , Garcia-Orellana, J. , Cochran, J. K. , Mas, J. L. , Chamizo, E. \& Hanfland, C. (2011). Radionuclides as tools to study the role of the Arctic Sea Ice in the interception, transport and redistribution of particulate matter and chemical species, 43th International Liège Colloquium on Ocean Dynamcis, May 2-6, 2011, Liège, Belgium.

Cámara -Mor, P. (2012). Radionuclides in the Arctic Ocean : Tracing sea ice origin, drifting and interception of atmospheric fluxes. Universitat Autònoma De Barcelonainstitut De Ciència I Tecnologia Ambientals. PhD thesis

Campbell, L. M., Norstrom, R. J., Hobson, K. A., Muir, D. C. G., Backus, S., \& Fisk, A. T. (2005). Mercury and other trace elements in a pelagic Arctic marine food web (Northwater Polynya, Baffin Bay). Science of the Total Environment, 351-352, 247-263.

Chmiel, S., Reszka, M., \& Rysiak, A. (2009). Heavy metals and radioactivity in environmental samples of the Scott Glacier Region on Spitsbergen in summer 2005. Quaestiones Geographicae, 28a/l.

Choppin, G. R., \& Morgenstern, A. (2001). Distribution and movement of environmental plutonium. Plutonium in the Environment, Proceedings of the Second International Symposium, 91-105.

Choudhary, S., Nayak, G. N., \& Khare N. (2020). Source, mobility, and bioavailability of metals in fjord sediments of Krossfjord-Kongsfjord system, Arctic, Svalbard. Environmental Science and Pollution Research, 27(1).

Chu, V. W. (2014). Greenland ice sheet hydrology: A review. Progress in Physical Geography, 38(1), 19-54.

Cogley, J. G., Hock, R., Rasmussen, L. A., Arendt, A. A., Bauder, A., Braithwaite, R .J., Jansson, P., Kaser, G., Möller, M., Nicholson, L., \& Zemp, M. (2011). Glossary of glacier mass balance and related terms, IHP-VII Technical Documents in Hydrology No. 86, IACS Contribution No. 2, UNESCO-IHP, Paris.

Conca, E., Abollino, O., Giacomino, A., Buoso, S., Traversi, R., Becagli, S., \& Malandrino, M. (2019). Source identification and temporal evolution of trace elements in PM10 collected near to Ny-Ålesund (Norwegian Arctic). Atmospheric Environment, 203, 153-165.

Cota, G. F., Cooper, L. W., Darby, D. A., \& Larsen, I. L. (2006). Unexpectedly high radioactivity burdens in icerafted sediments from the Canadian Arctic Archipelago. Science of the Total Environment, 366(1), 253-261.

Crane, K., Galasso, J., Brown, C., Cherkashov, G., Ivanov, G., Petrova, V., \& Vanstayan, B. (2001). Northern ocean inventories of organochlorine and heavy metal contamination. Marine Pollution Bulletin, 43(1-6), 28-60.

Cwanek, A., Łokas, E., Dinh, C. N., Zagórski, P., Singh, S. M., Szufa, K., \& Tomankiewicz, E. (2020). 90Sr level and behaviour in the terrestrial environment of Spitsbergen. Journal of Radioanalytical and Nuclear Chemistry, 327, 485-494.

Dallmann W. K. (2015). Geoscience Atlas of Svalbard. Volume 148 of Norsk Polarinstitutt, Rapportserie. Issue 148 of Rapport (Norsk polarinstitutt), Norsk Polarinstitutt, ISSN 0803-0421 Volume 148 of Report series. 
Dahlgaard, H. (1995). Transfer of European coastal pollution to the Arctic: Radioactive tracers. Marine Pollution Bulletin, 31, 3-7.

Dowdall, M., Gerland, S., \& Lind, B. (2003). Gamma-emitting natural and anthropogenic radionuclides in the terrestrial environment of Kongsfjord, Svalbard. The Science of the Total Environment, 305(1-3), 229-240.

Dowdall, M., Vicat, K., Frearson, I., Gerland, S., Lind, B., \& Shaw, G. (2004). Assessment of the radiological impacts of historical coal mining operations on the environment of Ny-Ålesund Svalbard. Journal of Environmental Radioactivity, 71(2), 101-114.

Dethleff, D., Nies, H., Harms, I., \& Karcher, M. (2000). Transport of radionuclides by sea-ice and dense-water formed in western Kara Sea flaw leads. Journal of Marine Systems, 24(3-4), 233-248.

Dietz, R., Sonne, C., Basu, N., Braune, B., O’Hara, T., Letcher, R. J., Aars, J., et al. (2013). What are the toxicological effects of mercury in Arctic biota? Science of the Total Environment, 443, 775-790.

Drevnick, P. E., Yang, H., Lamborg, C. H., \& Rose, N. L. (2012). Net atmospheric mercury deposition to Svalbard: Estimates from lacustrine sediments. Atmospheric Environment, 59, 509-513.

Drbal, K., Elster, J., \& Komarek, J. (1992). Heavy metals in water, ice and biological material from Spitsbergen Svalbard. Polar Research, 11(2), 99-101.

Durães, N., Novo, L. A. B., Candeias, C., \& da Silva, E. F. (2018). Distribution, transport and fate of pollutants. Soil Pollution, 29-57.

Eckhardt, S., Hermansen, O., Grythe, H., Fiebig, M., Stebel, K., Cassiani, M., Baecklund, A., \& Stohl, A. (2013). The influence of cruise ship emissions on air pollution in Svalbard - a harbinger of a more polluted Arctic? Atmospheric Chemistry and Physics Discussions, 13(1), 3071-3093.

Elberling, B., Asmund, G., Kunzendorf, H., \& Krogstad, E. J. (2002). Geochemical trends in metal-contaminated fiord sediments near a former lead-zinc mine in West Greenland. Applied Geochemistry, 17(4), 493-502.

Evengard, B., Berner, J., Brubaker, M., Mulvad, G., \& Revich, B. (2011). Climate change and water security with a focus on the Arctic. Global Health Action, 4(1), 8449.

Evenset, A., Christensen, G. N., Skotvold, T., Fjeld, E., Schlabach, M., Wartena, E., \& Gregor, D. (2004). A comparison of organic contaminants in two high Arctic lake ecosystems, Bjørnøya (Bear Island) Norway. Science of the Total Environment, 318(1-3), 125-141.

Evenset, A., Carroll, J., Christensen, G. N., Kallenborn, R., Gregor, D., \& Gabrielsen, G. W. (2007). Seabird guano is an efficient conveyer of persistent organic pollutants (POPs) to Arctic lake ecosystems. Environmental Science \& Technology, 41(4), 1173-1179.

Fong-McMaster, C., Konji, S., Nitschke, A., \& Konkle, A. T. (2020). Canadian Arctic contaminants and their effects on the maternal brain and behaviour: A scoping review of the animal literature. International Journal of Environmental Research and Public Health, 17(3), 926.

Frankowski, M., \& Zioła-Frankowska, A. (2013). Analysis of labile form of aluminum and heavy metals in bottom sediments from Kongsfjord, Isfjord, Hornsund fjords. Environmental Earth Sciences, 71(3), 1147-1158.

Fürst, J. J., Navarro, F., Gillet-Chaulet, F., Huss, M., Moholdt, G., Fettweis, \& X. Braun, M. H. (2018). The ice-free topography of Svalbard. Geophysical Research Letters.

Gerland, S., Lond, M., Dowdall, M., Kolstad, A. K., \& Brugot, A. L. (2002). Radionuclides in the Kongsfjorden area, Svalbard. Radioprotection - Colloque, 37(C1), 801-807.

Gobeil, C., MacDonald, R. W., Smith, J. N., \& Beaudin, L. (2001). Atlantic water flow pathways revealed by lead contamination in Arctic Basin sediments. Science, 293, 1301-1304.

Godzik, B. (1991). Heavy metals and macroelements in the tundra of southern Spitsbergen. Polar Research, 9, 121-131.

Gopikrishna, V. G., Kannan, V. M., Binish, M. B., Abdul Shukkur, M., Krishnan, K. P., \& Mohan, M. (2020). Mercury in the sediments of freshwater lakes in Ny-Ålesund, Arctic. Environmental Monitoring and Assessment, 192(8).

Granberg, M. E., Ask, A., \& Gabrielsen, G. G. (2017). Local contamination in Svalbard. Overview and suggestions for remediation actions. Troms $\phi$. Report no. 044.

Grotti, M., Soggia, F., Ianni, C., \& Udisti, R. (2013). Bioavailability of trace elements in surface sediments from Kongsfjorden Svalbard. Marine Pollution Bulletin, 77(1-2), 367-374.

Gulińska, J., Rachlewicz, G., Szczuciński, W., Barałkiewicz, D., Kózka, M., Bulska, E., \& Burzyk, M. (2003). Soil contamination in high Arctic areas of human impact, central Spitsbergen Svalbard. Polish Journal of Environmental Studies, 12(6), 701-707.

Gwynn, J. P., Dowdall, M., Davids, C., Selnæs, Ø. G., \& Lind, B. (2004). The radiological environment of Svalbard. Polar Research, 23(2), 167-180.

Gwynn, J. P., Andersen, M., Fuglei, E., Lind, B., Dowdall, M., Lydersen, C., \& Kovacs, K. (2005). Radionuclides in marine and terrestrial mammals of Svalbard. Norwegian Radiation Protection Authority Rapport, 2005, 7.

Hagen, J. O., Kohler, J., Melvold, K., \& Winther, J. G. (2003). Glaciers in Svalbard: Mass balance, runoff and freshwater flux. Polar Research, 22(2), 145-159.

Halbach, K., Mikkelsen, Ø., Berg, T., \& Steinnes, E. (2017). The presence of mercury and other trace metals in surface soils in the Norwegian Arctic. Chemosphere, 188, 567-574.

Hall, L. W., \& Anderson, R. D. (1995). The influence of salinity on the toxicity of various classes of chemicals to aquatic biota. Critical Reviews in Toxicology, 25(4), 281-346.

Heikkinen, P., Korkka-Niemi, K., Lahti, M., et al. (2002). Groundwater and surface water contamination in the area of the Hitura nickel mine Western Finland. Environmental Geology, 42(4), 313-329.

Heldal, H. E., Varskog, P., \& Føyn, L. (2002). Distribution of selected anthropogenic radionuclides $\left({ }^{137} \mathrm{Cs},{ }^{238} \mathrm{Pu}\right.$, ${ }^{239,240} \mathrm{Pu}$ and ${ }^{241} \mathrm{Am}$ ) in marine sediments with emphasis on the Spitsbergen-Bear Island area. Science of the Total Environment, 293(1-3), 233-245.

Heldal, H. E., Vikebø, F., \& Johansen, G. O. (2013). Dispersal of the radionuclide caesium-137 $\left({ }^{137} \mathrm{Cs}\right)$ from point sources in the Barents and Norwegian Seas and its potential contamination of the Arctic marine food 
chain: Coupling numerical ocean models with geographical fish distribution data. Environmental Pollution, 180, 190-198.

Headley, A. D. (1996). Heavy metal concentrations in peat profiles from the high Arctic. Science of the Total Environment, 177(1-3), 105-111.

Holden, A. V., \& Marsden, K. (1967). Organochlorine pesticides in seals and porpoises. Nature, 216, 1274-1276.

Hong, S., Candelone, J.-P., Patterson, C. C., \& Boutron, C. F. (1994). Greenland ice evidence of hemispheric lead pollution two millennia ago by Greek and Roman civilizations. Science, 265, 1841-1843.

Hop, H., Sagerup, K., Schlabach, M., \& Gabrielsen, G. W. (2001). Persistent organic pollutants in marine macrobenthos near urban settlements in Svalbard; Longyearbyen, Pyramiden, Barentsburg, and Ny-Ålesund. Norwegian Polar institute report no.8.

Hudelson, K. E., Drevnick, P. E., Wang, F., Armstrong, D., \& Fisk, A. T. (2020). Mercury methylation and demethylation potentials in Arctic lake sediments. Chemosphere, 248, 126001.

IsaksenNordli Førland, K. Ø. E. J., Łupikasza, E., Eastwood, S., \& Niedźwiedź, T. (2016). Recent warming on Spitsbergendinfluence of atmospheric circulation and sea ice cover. Journal of Geophysical Research - Atmospheres, 121(20), 11913-11931.

Isaksson, E., Hermanson, M., Hicks, S., Igarashi, M., Kamiyama, K., Moore, J., \& Watanabe, O. (2003). Ice cores from Svalbard-Useful archives of past climate and pollution history. Physics and Chemistry of the Earth, Parts A/b/c, 28(28-32), 1217-1228.

Jæger, I., Hop, H., \& Gabrielsen, G. (2009). Biomagnification of mercury in selected species from an Arctic marine food web in Svalbard. Science of the Total Environment, 407(16), 4744-5475.

Jiang, S., Liu, X., \& Chen, Q. (2011). Distribution of total mercury and methylmercury in lake sediments in Arctic Ny-Ålesund. Chemosphere, 83(8), 1108-1116.

Johansen, P., Hansen, M. M., Asmund, G., \& Nielsen, P. B. (1991). Marine organisms as indicators of heavy metal pollution-experience from 16 years of monitoring at a lead zinc mine in Greenland. Chemistry and Ecology, 5(1-2), 35-55.

Johansen, S., Poste, A., Allan, I., Evenset, A., \& Carlsson, P. (2021). Terrestrial inputs govern spatial distribution of polychlorinated biphenyls (PCBs) and hexachlorobenzene (HCB) in an Arctic fjord system (Isfjorden, Svalbard). Environmental Pollution (Barking, Essex : 1987), 281, 116963.

Johannessen, O. M., Volkov, V. A., Pettersson, L. H., Maderich, V. S., Zheleznyak, M.J., Gao, Y., Bobylev, L .P., Stepanov, A. V., Neelov, I. A., Tishkov, V. P., \& Nielsen, S. P. (2010). Radioactivity and pollution in the Nordic seas and Arctic region. Observations, modeling and simulation. Springer, Nansen Center's Polar Series, 408.

Kalinowska, A., Szopińska, M., Chmiel, S., Kończak, M., Polkowska, Ż, Artichowicz, W., Jankowska, K., Nowak, A., \& Łuczkiewicz, A. (2020). Heavy metals in a high Arctic Fiord and their introduction with the wastewater: A case study of Adventfjorden-Longyearbyen System Svalbard. Water, 12, 794.
Khan, A. L., Dierssen, H., Schwarz, J. P., Schmitt, C., Chlus, A., Hermanson, M., \& McKnight, D. M. (2017). Impacts of coal dust from an active mine on the spectral reflectance of Arctic surface snow in Svalbard Norway. Journal of Geophysical Research: Atmospheres, 122(3), 1767-1778.

Kim, H., Kwon, S. Y., Lee, K., Lim, D., Han, S., Kim, T. W., Joo, Y. J., Lim, J., Kang, M. H., \& Nam, S. I. (2020). Input of terrestrial organic matter linked to deglaciation increased mercury transport to the Svalbard fjords. Scientific Reports, 10(1), 3446.

Kirk, J. L., Lehnherr, I., Andersson, M., Braune, B. M., Chan, L., Dastoor, A. P., \& St. Louis, V. L. (2012). Mercury in Arctic marine ecosystems: Sources, pathways and exposure. Environmental Research, 119, 64-87.

Klaminder, J., Hammarlund, D., Kokfelt, U., Vonk, J. E., \& Bigler, C. (2010). Lead contamination of subarctic lakes and its response to reduced atmospheric fallout: Can the recovery process be counteracted by the ongoing climate change? Environmental Science \& Technology, 44(7), 2335-2340.

Kłos, A., Ziembik, Z., Rajfur, M., Dołhańczuk-Śródka, A., Bochenek, Z., Bjerke, J. W., \& Godyń, P. (2017). The origin of heavy metals and radionuclides accumulated in the soil and biota samples collected in Svalbard, near Longyearbyen. Ecological Chemistry and Engineering $S$, 24(2), 223-238.

Kohler, J., James, T., Murray, T., Nuth, C., Brandt, O., Barrand, N., Aas H., \& Luskman A. (2007). Acceleration in thinning rate on western Svalbard glaciers. Geophysical Research Letters 34(18).

Kosek, K., Luczkiewicz, A., Kozioł, K., Jankowska, K., Ruman, M., \& Polkowska, Ż. (2018). Environmental characteristics of a tundra river system in Svalbard. Part 1: Bacterial abundance, community structure and nutrient levels. Science of the Total Environment, 653, 1571-1584.

Kozak, K., Kozioł, K., Luks, B., Chmiel, S., Ruman, M., Marć, M., \& Polkowska, Ż. (2015). The role of atmospheric precipitation in introducing contaminants to the surface waters of the Fuglebekken catchment Spitsbergen. Polar Research, 34(1), 24207.

Kozak, K., Polkowska, Ż, Stachnik, Ł, Luks, B., \& Chmie, 1 S., Ruman, M., Simeonov, V. . (2016). Arctic catchment as a sensitive indicator of the environmental changes: Distribution and migration of metals (Svalbard). International Journal of Environmental Science and Technology, 13(12), 2779-2796.

Krickov, I. V., Lim, A. G., Manasypov, R. M., Loiko, S. V., Vorobyev, S. N., Shevchenko, V. P., \& Pokrovsky, O. S. (2019). Major and trace elements in suspended matter of western Siberian rivers: First assessment across permafrost zones and landscape parameters of watersheds. Geochimica et Cosmochimica Acta.

Kristiansen, S. M., Leinaas, H. P., Herzke, D., Hylland, K., Gabrielsen, G. W., Harju, M., \& Borgå, K. (2019). Seabirdtransported contaminants are reflected in the Arctic tundra, but not in its soil-dwelling springtails (Collembola). Environmental Science \& Technology.

Lecher, A. (2017). Groundwater discharge in the Arctic: A review of studies and implications for biogeochemistry. Hydrology, 4(3), 41. 
Leppänen, A. P., Kasatkina, N., Vaaramaa, K., Matishov, G. G., \& Solatie, D. (2013). Selected anthropogenic and natural radioisotopes in the Barents Sea and off the western coast of Svalbard. Journal of Environmental Radioactivity, 126, 196-208.

Lepper, P. (2005). Manual on the methodological framework to derive environmental quality standards for priority substances in accordance with Article 16 of the Water Framework Directive (2000/60/EC).

Lim, A. G., Jiskra, M., Sonke, J. E., Loiko, S. V., Kosykh, N., \& Pokrovsky, O. S. (2020). A revised pan-Arctic permafrost soil $\mathrm{Hg}$ pool based on Western Siberian peat $\mathrm{Hg}$ and carbon observations. Biogeosciences, 17(12), 3083-3097.

Liu, X., Jiang, S., Zhang, P., \& Xu, L. (2012). Effect of recent climate change on Arctic $\mathrm{Pb}$ pollution: A comparative study of historical records in lake and peat sediments. Environmental Pollution, 160, 161-168.

Liu, G., Wang, J., Liu, X., Liu, X., Li, X., Ren, Y., \& Dong, L. (2018). Partitioning and geochemical fractions of heavy metals from geogenic and anthropogenic sources in various soil particle size fractions. Geoderma, 312, 104-113.

Lu, Z., Cai, M., Wang, J., Yin, Z., \& Yang, H. (2012). Levels and distribution of trace metals in surface sediments from Kongsfjorden, Svalbard. Norwegian Arctic. Environmental Geochemistry and Health, 35(2), 257-269.

Lüdke, Ch., Skole, J., Taubner, K., \& Krievs, M. (2005). Trace metal analysis in arctic aerosols by an inductively coupled plasma-time of flight-mass spectrometer combined with an inductively heated vaporizer. Spectrochimica Acta Part B, 60, 1412-1422.

Łokas, E., Mietelski, J. W., Ketterer, M. E., Kleszcz, K., Wachniew, P., Michalska, S., \& Miecznik, M. (2013). Sources and vertical distribution of ${ }^{137} \mathrm{Cs},{ }^{238} \mathrm{Pu},{ }^{239+240} \mathrm{Pu}$ and ${ }^{241} \mathrm{Am}$ in peat profiles from southwest Spitsbergen. Applied Geochemistry, $28,100-108$.

Łokas, E., Zaborska, A., Kolicka, M., Różycki, M., \& Zawierucha, K. (2016). Accumulation of atmospheric radionuclides and heavy metals in cryoconite holes on an Arctic glacier. Chemosphere, 160, 162-172.

Łokas, E., Wachniew, P., Jodłowski, P., \& Gśsiorek, M. (2017). Airborne radionuclides in the proglacial environment as indicators of sources and transfers of soil material. Journal of Environmental Radioactivity, 178-179, 193-202.

Łokas, E., Zaborska, A., Sobota, I., Gaca, P., Milton, J. A., Kocurek, P., \& Cwanek, A. (2019). Airborne radionuclides and heavy metals in high Arctic terrestrial environment as the indicators of sources and transfers of contamination. The Cryosphere, 13(7), 2075-2086.

M-608: Grenseverdier for klassifisering av vann, sediment og biota. (2020). Vannforvaltning Vann, hav og kyst Miljøovervåking og naturkartlegging. Miljødirektoratet.

Maccali, J., Hillaire-Marcel, C., Carignan, J., et al. (2013). Geochemical signatures of sediments documenting Arctic sea-ice and water mass export through Fram Strait since the last glacial maximum. Quaternary Science Reviews, 64, 136-151.

Macdonald, R. W., Barrie, L. A., Bidleman, T. F., Diamond, M. L., Gregor, D. J., Sernkin, R. G., Strachan, W. M. J., Li, Y. F., Wania, F., Alaee, M., Alexeeva, L. B., Backus, S. M., Bailey, R., Bewers, J. M., Gobeil, C., Halsall, C. J.,
Harner, T., Hoff, I. T., Jantunen, L. M. M., ... Yunker, M. B. (2000). Sources, occurrence and pathways of contaminants in the Canadian Arctic: A review. The Science of the Total Environment, 122(1-2), 1-74.

Macdonald, R. W. (2001). The Arctic Ocean and contaminants: Pathways that lead to us. Waters in Peril, 135-149.

Macdonald, R. W., Harner, T. T., \& Fyfe, J. (2005). Recent climate change in the Arctic and its impact on contaminants pathway and interpretation on temporal trend data. The Science of the Total Environment, 342, 5-86.

Macdonald, R. W., \& Loseto, L. L. (2010). Are Arctic Ocean ecosystems exceptionally vulnerable to global emissions of mercury? A call for emphasised research on methylation and the consequences of climate change. Environmental Chemistry, 7, 133-138.

Masque, P., Cochran, J. K., Hirschberg, D. J., Derhleff, D., Hebbeln, D., Winkler, A., \& Pfirman, S. (2007). Radionuclides in Arctic sea ice: Tracers of sources, fates and ice transit time scales. Deep Sea Research Part I: Oceanographic Research Papers, 54(8), 1289-1310.

Melke, J. (2006). The contents of selected trace elements in the soils of Bellsund, Spitsbergen. Polish Journal of Soil Science, 39, 21-32.

Mezaki, Y., Kato, S., Nishikawa, O., Takashima, I., Tsubokura, M., Minowa, H., Asakura, T., Matsuura, T., \& Senoo, H. (2019). Measurements of radiocesium in animals, plants and fungi in Svalbard after the Fukushima Daiichi nuclear power plant disaster. Heliyon, 5(12), e0351.

McGovern, M., Poste, A. E., Oug, E., Renaud, P. E., \& Trannum, H. C. (2020). Riverine impacts on benthic biodiversity and functional traits: A comparison of two sub-Arctic fjords. Estuarine. Coastal and Shelf Science, 240, 106774.

Negoiţă, T., \& Ropotă, M. (2000). Heavy metal ions determination in the Arctic soils. Analytical Letters, 33, 729-738.

Meredith, M., \& Sommerkorn, M. (2019). Polar Regions. In: IPCC Special Report on the Ocean and Cryosphere in a Changing Climate [H. O. Pörtner, D.C. Roberts, V. Masson-Delmotte, P. Zhai, M. Tignor, E. Poloczanska, K. Mintenbeck, A. Alegría, M. Nicolai, A. Okem, J. Petzold, B. Rama, N.M. Weyer (eds.)]. In press.

Mitchell, P. I., Batlle, J. V., Ryan, T. P., McEnri, C., Long, S., O'Colmain, M., \& Ledgerwood, F. K. (1991). Plutonium, Americtum and Radiocaesium in Sea Water, Sediments and Coastal Soils in Carlingford Lough. Radionuclides in the Study of Marine Processes, 265-275.

Mohan, M., Sreelakshmi, U., Vishnu Sagar, M. K., Gopikrishna, V. G., Pandit, G. G., Sahu, S. K., \& Krishnan, K. P. (2018). Rate of sediment accumulation and historic metal contamination in a tidewater glacier fjord, Svalbard. Marine Pollution Bulletin, 131, 453-459.

Moreno-Ibáñez, M., Hagen, J. O., Hübner, C., Lihavainen, H., \& Zaborska, A. (eds). (2021). SESS report 2020, Svalbard Integrated Arctic Earth Observing System, Longyearbyen.

Muir, D., Braune, B., DeMarch, B., Norstrom, R., Wagemann, R., Lockhart, L., Hargrave, B., Bright, D., Addison, R., Payne, J., \& Reimier, K. (1999). Spatial and temporal trends and effects of contaminants in the Canadian Arctic marine ecosystem: A review. The Science of the Total Environment, 230, 83-144. 
Nowak, A., Hodgkins, R., Nikulina, A., Osuch, M., Wawrzyniak, T., \& Kavan, J. (2021). From land to fjords: The review of Svalbard hydrology from 1970 to 2019. Loughborough University. Chapter. https://hdl.handle.net/2134/14225972.v1

Ottesen, R.T., Bogen, J., Finne, T.E. (2010). Geochemical atlas of Norway, Part 2: Geochemical Atlas of Spitsbergen. Geological Survey of Norway (NGU), Trondheim, $160 \mathrm{pp}$.

Orheim, A., Bieg, G., Brekke, T., Horseide, V., \& Stenvold, J. (2007). Petrography and geochemical affinities of Spitsbergen Paleocene coals Norway. International Journal of Coal Geology, 70(1-3), 116-136.

Overland, J., Dunlea, E., Box, J. E., Corell, R., Forsius, M., Kattsov, V., Olsen, M. S., Pawlak, J., Reiersen, L.-O., \& Wang, M. (2018). The urgency of Arctic change. Polar Science, 21, 6-13.

Øverjordet, I. B., Gabrielsen, G. W., Berg, T., Ruus, A., Evenset, A., Borgå, K., Christensen, G., Lierhagen, S., \& Jenssen, B. M. (2015a). Effect of diet, location and sampling year on bioaccumulation of mercury, selenium and cadmium in pelagic feeding seabirds breeding at Svalbard. Chemosphere, 122, 14-22.

Øverjordet, I. B., Kongsrud, M. B., Gabrielsen, G. W., Berg, T., Ruus, A., Evenset, A., Borgå, K., Christensen, G., \& Jenssen, B. M. (2015b). Toxic and essential elements changed in black-legged kittiwakes (Rissa tridactyla) during their stay in an Arctic breeding area Svalbard. Science of the Total Environment, 502, 548-556.

Pacyna-Kuchta, A. D., Jakubas, D., Frankowski, M., Polkowska, Ż, \& Wojczulanis-Jakubas, K. (2020). Exposure of a small Arctic seabird, the little auk (Alle alle) breeding in Svalbard, to selected elements throughout the course of a year. Science of the Total Environment, 732, 139103.

Paquin, P .R., Farley, K., Santore, R. C., Kavadas, C. D., Mooney, C. G., Wu, K.-B., \& Di Toro, D. M. (2003). Metals in aquatic systems: A review of exposure bioaccumulation, and toxicity models. SETAC, Pensacola.

Park, J., Kim, S., Yoo, J., et al. (2014). Effect of salinity on acute copper and zinc toxicity to Tigriopus japonicus: The difference between metal ions and nanoparticles. Marine Pollution Bulletin, 85, 526-531.

Pawłowska, J., Zajączkowski, M., Szczuciński, W., Zaborska, A., Kucharska, M., Jernas, P. E., \& Forwick, M. (2017). The influence of Coriolis force driven water circulation on the palaeoenvironment of Hornsund (S Spitsbergen) over the last century. Boreas, 46(4), 737-749.

Pavlov, V. K., \& Stanovoy, V. V. (2001). The problem of transfer of radionuclide pollution by sea ice. Marine Pollution Bulletin, 42(4), 319-323.

Pavlov, V., Pavlova, O., \& Korsnes, R. (2004). Sea ice fluxes and drift trajectories from potential pollution sources, computed with a statistical sea ice model of the Arctic Ocean. Journal of Marine Systems, 48, 133-157.

Periáñez, R., Bezhenar, R., Brovchenko, I., Duffa, C., Iosjpe, M., Jung, K. T., \& de With, G. (2019). Marine radionuclide transport modelling: Recent developments, problems and challenges. Environmental Modelling \& Software, 104523.

Perner, K., Leipe, T., Dellwig, O., Kuijpers, A., Mikkelsen, N., Andersen, T. J., \& Harff, J. (2010). Contamination of Arctic fjord sediments by $\mathrm{Pb}-\mathrm{Zn}$ mining at Maarmorilik in central West Greenland. Marine Pollution Bulletin, 60(7), 1065-1073.

Perryman, C. R., Wirsing, J., Bennett, K. A., Brennick, O., Perry, A. L., Williamson, N., \& Ernakovich, J. G. (2020). Heavy metals in the Arctic: Distribution and enrichment of five metals in Alaskan soils. PLoS ONE, 15(6), e0233297.

Pinglot, J. F., Pourchet, M., Lefauconnier, B., Hagen, J. O., Isaksson, E., Vaikm, R., \& Kamiyama, K. (1999). Accumulation in Svalbard glaciers deduced from ice cores with nuclear tests and Chernobyl reference layers. Polar Research, 18(2), 315-321.

Pouch, A., Zaborska, A., Mazurkiewicz, M., Winogradow, A., \& Pazdro, K. (2021). PCBs, HCB and PAHs in the seawater of Arctic fjords - Distribution, sources and risk assessment. Marine Pollution Bulletin, 164, 111980.

Pouch, A., Zaborska, A., \& Pazdro, K. (2017). Concentrations and origin of polychlorinated biphenyls (PCBs) and polycyclic aromatic hydrocarbons (PAHs) in sediments of western Spitsbergen fjords (Kongsfjorden, Hornsund, and Adventfjorden). Environmental Monitoring and Assessment, 189(4).

Pouch, A., Zaborska, A., \& Pazdro, K. (2018). The history of hexachlorobenzene accumulation in Svalbard fjords. Environmental Monitoring and Assessment, 190(6).

Prandle, D. (1984). A modelling study of the mixing of ${ }^{137} \mathrm{Cs}$ in the seas of the European Continental Shelf Transactions of the Royal Society a: Mathematical. Physical and Engineering Sciences, 310(1513), 407-436.

Richter-Menge, J., M. L. Druckenmiller, and M. Jeffries, Eds., 2019. Arctic Report Card 2019,https://www.arctic.noaa. gov/Report-Card.

Rissanen, K., Ikaeheimonen, T. K., Matishov, D., \& Matishov, G. G. (1997). Radioactivity levels in fish, benthic fauna, seals and sea birds collected in the northwest arctic of Russia. Radioprotection. Pt.1. Inventories, behaviour and processes.

Rose, N. L., Rose, C. L., Boyle, J. F., \& Appleby, P. G. (2004). Lake-sediment evidence for local and remote sources of atmospherically deposited pollutants on Svalbard. Journal of Paleolimnology, 31(4), 499-513.

Ruus, A., Øverjordet, I. B., Braaten, H. F., Evenset, A., Christensen, G., Heimstad, E. S., Gabrielsen, G. W., \& Borgå, K. (2015). Methylmercury biomagnification in an Arctic pelagic food web. Environmental Toxicology and Chemistry, 9999, 1-8.

Sagar Vishnu M.K., Kannan V.M., Gopikrishna V.G., Krishnan K.P., Mahesh Mohan (2021) Geochemistry and distribution of Metals in the Sediments of Kongsfjorden, Svalbard, Arctic. Regional Studies in Marine Science, 44, 101729.

Salomons, W., \& Förstner, U. (1984). Sediments and the transport of metals. Metals in the Hydrocycle, 63-98.

Samecka-Cymerman, A., Wojtuń, B., Kolon, K., \& Kempers, A. J. (2011). Sanionia uncinata (Hedw.) Loeske as bioindicator of metal pollution in polar regions. Polar Biology, 34, 381-388.

Saniewski, M., \& Borszcz, T. (2017). ${ }^{90} \mathrm{Sr}$ and ${ }^{137} \mathrm{Cs}$ in Arctic echinoderms. Marine Pollution Bulletin, 124, 563-568.

Saremi, S., Isaksson, M., \& Harding, K. C. (2018). Bio accumulation of radioactive caesium in marine mammals in the Baltic 
Sea - Reconstruction of a historical time series. Science of the Total Environment, 631-632, 7-12.

Schuster, P. F., Schaefer, K. M., Aiken, G. R., Antweiler, R. C., Dewild, J. F., Gryziec, J. D., \& Zhang, T. (2018). Permafrost stores a globally significant amount of mercury. Geophysical Research Letters, 45(3), 1463-1471.

Schuler, T. V., Kohler, J., Elagina, N., Hagen, J. O. M., Hodson, A. J., Jania, J. A., \& Van Pelt, W. J. J. (2020). Reconciling Svalbard glacier mass balance. Frontiers in Earth Science, 8 .

Shevchenko, V. P. (2003). The influence of aerosols on the oceanic sedimentation and environmental conditions in the Arctic. Berichte Zur Polar Und Meeresforschung (reports on Polar and Marine Research) Bremerhaven, Alfred Wegener Institute for Polar and Marine Research, 464, 149.

Siegel, F. R., Galasso, J. L., Kravitz, J. H., \& Basinger, W. D. (2000). The Svalbard western coast: Site of baseline geochemistry and incipient contamination. Environmental Geology, 39(7), 816-822.

Singh, S. M., Sharma, J., Gawas-Sakhalkar, P., Upadhyay, A. K., Naik, S., Pedneker, S. M., \& Ravindra, R. (2012). Atmospheric deposition studies of heavy metals in Arctic by comparative analysis of lichens and cryoconite. Environmental Monitoring and Assessment, 185(2), 1367-1376.

Skjerdal, H1, Heldal, HE2, Rand, A3, Gwynn, J1, Jensen, LK1, Volynkin, A2, Haanes, H1, Møller, B1, Liebig, PL2, \& Gäfvert, T1 (2020). Radioactivity in the Marine Environment 2015, 2016 and 2017. Results from the Norwegian Marine Monitoring Programme RAME. DSA Report 2020:04. Østerås: Norwegian Radiation and Nuclear Safety Authority.

Smith, J. N., Ellis, K. M., Polyak, L., Ivanov, G., Forman, S. L., \& Moran, S. B. (2000). 239,240Pu transport into the Arctic Ocean from underwater nuclear tests in Chernaya Bay Novaya Zemlya. Continental Shelf Research, 20(3), 255-279.

Song, C., Wang, G., Mao, T., Dai, J., \& Yang, D. (2019). Linkage between permafrost distribution and river runoff changes across the Arctic and the Tibetan Plateau. Science China Earth Sciences 62.

Souter, L., \& Watmough, S. A. (2016). The impact of drought and air pollution on metal profiles in peat cores. Science of the Total Environment, 541, 1031-1040.

Søndergaard, J., Tamstorf, M., Elberling, B., Larsen, M. M., Mylius, M. R., Lund, M., \& Rigét, F. (2015). Mercury exports from a high-Arctic river basin in Northeast Greenland $\left(74^{\circ} \mathrm{N}\right)$ largely controlled by glacial lake outburst floods. Science of the Total Environment, 514, 83-91.

Spolaor, A., Moroni, B., Luks, B., Nawrot, A., Roman, M., Larose, C., Stachnik, Ł, Bruschi, F., Kozioł, K., Pawlak, F., Turetta, C., Barbaro, E., Gallet, J.-C., \& Cappelletti, D. (2021). Investigation on the sources and impact of trace elements in the annual snowpack and the firn in the Hansbreen (Southwest Spitsbergen). Frontiers in Earth Science, 8, 536036.

St. Pierre, K. A., St. Louis, V. L., Lehnherr, I., Schiff, S. L., Muir, D. C. G., Poulain, A. J., ... Gardner, A. S. (2019). Contemporary limnology of the rapidly changing glacierized watershed of the world's largest High Arctic lake. Scientific Reports, 9(1).

Stern, G. A., Macdonald, R. W., Outridge, P. M., Wilson, S., Chételat, J., Cole, A., \& Zdanowicz, C. (2012). How does climate change influence arctic mercury? Science of the Total Environment, 414, 22-42.

Stein R. (2008). Chapter two modern physiography, hydrology, climate, and sediment input. Developments in Marine Geology 2.

Sternal, B., Junttila, J., Skirbekk, K., Forwick, M., Carroll, J., \& Pedersen, K. B. (2017). The impact of submarine copper mine tailing disposal from the 1970s on Repparfjorden, northern Norway. Marine Pollution Bulletin, 120, 136-153.

St. Pierre, K. A., St.Louis, V. L., Lehnherr, I., Gardner, A., Serbu, J., Mortimer, C. A., \& Talbot, C. (2018). Drivers of mercury cycling in the rapidly changing glacierized watershed of the high Arctic's largest lake by volume (Lake Hazen, Nunavut, Canada). Environmental Science \& Technology.

Su, J., Shi, Q., Chen, P., \& Liang, H. (2019). The coupling characteristics of Arctic seaice concentration and seaice motion in winter. IGARSS 2019 - 2019 IEEE International Geoscience and Remote Sensing Symposium.

Sun, Q., Chu, G., Liu, J., \& Gao, D. (2006). A 150-year record of heavy metals in the varved sediments of Lake Bolterskardet, Svalbard. Arctic, Antarctic, and Alpine Research, 38(3), 436-445.

Thibodeaux, L. J., \& Bierman, V. I. (2003). The bioturbation-driven chemical release process. Environmental Science \& Technology, 37(13), 252-258.

Tkatcheva, V., Hyvärinen, H., Kukkonen, J., Ryzhkov, L. P., \& Holopainen, I. J. (2004). Toxic effects of mining effluents on fish gills in a subarctic lake system in NW Russia. Ecotoxicology and Environmental Safety, 57(3), 278-289.

Tolvanen, A., Eilu, P., Juutinen, A., Kangas, K., Kivinen, M., Markovaara-Koivisto, M., \& Similä, J. (2018). Mining in the Arctic environment - A review from ecological, socioeconomic and legal perspectives. Journal of Environmental Management.

Tovar-Sanchez, A., Duarte, C., Alonso, J.C., Lacorte, S., Tauler, R., \& Galban-Malagon, C. (2010). Impacts of metals and nutrients released from melting multiyear Arctic sea ice. Journal of Geophysical Research Oceans, 115, 7.

Van den Heuvel-Greve, M. J., Szczybelski, A. S., van den Brink, N. W., Kotterman, M. J. J., Kwadijk, C. J. A. F., Evenset, A., \& Murk, A. J. (2016). Low organotin contamination of harbour sediment in Svalbard. Polar Biology, 39(10), 1699-1709.

van Oostdam, J., Gilman, A., Dewailly, E., Usher, P., Wheatley, B., Kuhnlein, H., Neve, S., Walker, J., Tracy, B., Feeley, M., Jerome, Y., \& Kwavnick, B. (1999). Human health implications of environmental contaminants in Arctic Canada: A review. The Science of the Total Environment, $230,1-82$.

Veileder 02:2018 Klassifisering av miljøtilstand i vann. Økologisk og kjemisk klassifiseringssystem for kystvann, grunnvann, innsjøer og elver (2018). Direktoratsgruppen for gjennomføringen av vannforskriften. 
Vintró, L., McMahon, C. A., Mitchell, P. I., Josefsson, D., Holm, E., \& Roos, P. (2002). Transport of plutonium in surface and sub-surface waters from the Arctic shelf to the North Pole via the Lomonosov Ridge. Journal of Environmental Radioactivity, 60(1-2), 73-89.

Walker, T. ., Young, S. ., Crittenden, P. ., \& Zhang, H. (2003). Anthropogenic metal enrichment of snow and soil in north-eastern European Russia. Environmental Pollution, 121(1), 11-21.

Wawrzyniak, T., \& Osuch, M. (2020). A 40-year High Arctic climatological dataset of the polish Polar Station Hornsund (SW Spitsbergen, Svalbard). Earth System Science Data, 12, 805-815.

Webb, J. R., Santos, I. R., Maher, D. T., Tait, D. R., Cyronak, T., Sadat-Noori, M., \& Jeffrey, L. C. (2018). Groundwater as a source of dissolved organic matter to coastal waters: Insights from radon and CDOM observations in 12 shallow coastal systems. Limnology and Oceanography.

Węgrzyn, M., Wietrzyk, P., Lisowska, M., Klimek, B., \& Nicia, P. (2016). What influences heavy metals accumulation in arctic lichen Cetrariella delisei in Svalbard? Polar Science, 10(4), 532-540.

Węgrzyn, M. H., Wietrzyk, P., Lehmann-Konera, S., Chmiel, S., Cykowska-Marzencka, B., \& Polkowska, Ż. (2018). Annual variability of heavy metal content in Svalbard reindeer faeces as a result of dietary preferences. Environmental Science and Pollution Research, 25(36), 36693-36701.

Węsławski, J. M., Koszteyn, J., Zajączkowski, M., Wiktor, J., \& Kwaśniewski, S. (1995). Fresh water in Svalbard fjord ecosystems. In H.R. Skjoldal et al. (eds.): Ecology of fjords and coastal waters, 229-242.

Wojtuń, B., Samecka-Cymerman, A., Kolon, K., Kempers, A., \& Skrzypek, G. (2013). Metals in some dominant vascular plants, mosses, lichens, algae, and the biological soil crust in various types of terrestrial tundra, SW Spitsbergen, Norway. Polar Biology 36(12).

Wojtysiak, K., Herman, A., \& Moskalik, M. (2018). Wind wave climate of west Spitsbergen: Seasonal variability and extreme events. Oceanologia, 60(3), 331-343.

Ye, B., Yang, D., Zhang, Z., \& Kane, D. L. (2009). Variation of hydrological regime with permafrost coverage over Lena Basin in Siberia. Journal of Geophysical Research, 114(D7).
Ytreberg, E., Karlsson, J., Ndungu, K., et al. (2011). Influence of salinity and organic matter on the toxicity of $\mathrm{Cu}$ to a brackish water and marine clone of the red macroalga ceramium tenuicorne. Ecotoxicology and Environmental Safety, 74, 636-642.

Zaborska, A. (2017). Sources of ${ }^{137} \mathrm{Cs}$ to an Arctic fjord (Hornsund, Svalbard). Journal of Environmental Radioactivity, 180, 19-26.

Zaborska, A., Beszczyńska-Moller, A., \& WłodarskaKowalczuk, M. (2017). History of heavy metal accumulation in the Svalbard area: Distribution, origin and transport pathways. Environmental Pollution, 231, 437-450.

Zaborska, A., Strzelewicz, A., Rudnicka, P., \& Moskalik, M. (2020). Processes driving heavy metal distribution in the seawater of an Arctic fjord (Hornsund, southern Spitsbergen). Marine Pollution Bulletin, 161, 111719.

Zagórski, P., Rodzik, J., Moskalik, M., Strzelecki, M. C., Lim, M., Błaszczyk, M., et al. (2015). Multidecadal (19602011) shoreline changes in Isbjornhamna (Hornsund, Svalbard). Polish Polar Research, 4, 369-390.

Zajączkowski, M., Szczuciński, W., \& Bojanowski, R. (2004). Recent changes in sediment accumulation rates in Adventfjorden Svalbard. Oceanologia, 46(2), 217-231.

Zdanowicz, C., Krümmel, E. M., Lean, D., Poulain, A. J., Yumvihoze, E., Chen, J., \& Hintelmann, H. (2013). Accumulation, storage and release of atmospheric mercury in a glaciated Arctic catchment, Baffin Island, Canada. Geochimica Et Cosmochimica Acta, 107, 316-335.

Zhan, J., Gao, Y., Li, W., Chen, L., Lin, H., \& Lin, Q. (2014). Effects of ship emissions on summertime aerosols at $\mathrm{Ny}-$ Alesund in the Arctic. Atmospheric Pollution Research, 5(3), 500-510.

Ziółek, M., Bartmiński, P., \& Stach, A. (2017). The influence of seabirds on the concentration of selected heavy metals in organic soil on the Bellsund Coast, Western Spitsbergen. Arctic, Antarctic, and Alpine Research, 49(4), 507-520.

Publisher's Note Springer Nature remains neutral with regard to jurisdictional claims in published maps and institutional affiliations. 